\title{
A Critical Review of Animal Models Used in Acute Myeloid Leukemia Pathophysiology
}

\author{
Hala Skayneh ${ }^{1, \dagger}{ }^{+}$Batoul Jishi ${ }^{2, \dagger}$, Rita Hleihel ${ }^{3}$, Maguy Hamieh ${ }^{1,3}$, Nadine Darwiche ${ }^{4} \oplus$, \\ Ali Bazarbachi ${ }^{2,3}$, Marwan El Sabban $2, *, \ddagger$ and Hiba El Hajj 1,3,*, \\ 1 Department of Experimental Pathology, Microbiology and Immunology, Faculty of Medicine, \\ American University of Beirut, Beirut 1107 2020, Lebanon \\ 2 Department of Anatomy, Cell Biology and Physiological Sciences, Faculty of Medicine, American University \\ of Beirut, Beirut 1107 2020, Lebanon \\ 3 Department of Internal Medicine, Faculty of Medicine, American University of Beirut, \\ Beirut 1107 2020, Lebanon \\ 4 Department of Biochemistry and Molecular Genetics, Faculty of Medicine, American University of Beirut, \\ Beirut 1107 2020, Lebanon \\ * $\quad$ Correspondence: me00@aub.edu.lb (M.E.S.); he21@aub.edu.lb (H.E.H.) \\ $\dagger$ H.S. and B.J. contributed equally to this study. \\ $\ddagger$ H.E.H and M.E.S contributed equally to this study.
}

Received: 5 July 2019; Accepted: 1 August 2019; Published: 13 August 2019

check for updates

\begin{abstract}
Acute myeloid leukemia (AML) is one of the most frequent, complex, and heterogeneous hematological malignancies. AML prognosis largely depends on acquired cytogenetic, epigenetic, and molecular abnormalities. Despite the improvement in understanding the biology of AML, survival rates remain quite low. Animal models offer a valuable tool to recapitulate different AML subtypes, and to assess the potential role of novel and known mutations in disease progression. This review provides a comprehensive and critical overview of select available AML animal models. These include the non-mammalian Zebrafish and Drosophila models as well as the mammalian rodent systems, comprising rats and mice. The suitability of each animal model, its contribution to the advancement of knowledge in AML pathophysiology and treatment, as well as its advantages and limitations are discussed. Despite some limitations, animal models represent a powerful approach to assess toxicity, and permit the design of new therapeutic strategies.
\end{abstract}

Keywords: Zebrafish; Drosophila; rats; mice; NPM-1; FLT3 ITD; ETO-1; IDH1/2

\section{Introduction}

Acute myeloid leukemia (AML) is an aggressive and heterogeneous hematological group of neoplasms characterized by increased proliferation of myeloid progenitor cells and a reduced capacity to differentiate. This results in the accumulation of myeloblasts in the bone marrow (BM), which negatively impacts hematopoiesis and leads to BM failure [1]. AML is one of the most common acute leukemia in adults [2]. Its incidence rate is 2.5 per 100,000 cases/year and the median overall survival (OS) is approximately nine months [3]. AML treatment and prognosis largely depend on the patients' age [4-6]. AML was historically divided into eight major groups according to cell morphology and immune phenotype (M0 to M7) [7]. This classification has been revised several iterations since then [8-12]. Exome sequencing in AML patients led to the current classification through identification of more than 20 driver recurrent mutations [13]. These mainly include Nucleophosmin-1 (NPM1), DNA methyltransferase 3A (DNMT3A), Fms-like tyrosine kinase-3 (FLT3), isocitrate dehydrogenase (IDH), Ten-Eleven Translocation 2 (TET-2), Runt-related transcription factor (RUNX-1), CCAAT enhancer binding protein $\alpha(C E B P A)$, additional sex comb-like 1 (ASXL1), mixed lineage leukemia $(M L L)$, tumor protein $p 53$ 
(TP53), c-KIT [14]. These mutations dictate the response to treatment, rates of complete remission, disease-free survival, overall survival, and classify AML into three prognostic risk factors (favorable, intermediate, and adverse) (Table 1).

Animal models provide an excellent tool to understand the biology of pathological mechanisms involved in human diseases. Diverse animal species were used to answer pivotal questions related to disease progression, genetic mutations, immunity, and response to treatment. Among these models, Zebrafish was exploited to generate different mutations mimicking several subtypes of human AML.

Table 1. 2017 European LeukemiaNet (ELN) prognostic groups according to genetic abnormalities of acute myeloid leukemia (AML) [12].

\begin{tabular}{|c|c|}
\hline Prognostic Group & Genetic Mutations and Abnormalities \\
\hline Favorable & $\begin{array}{ll}\text { - } & \mathrm{t}(8 ; 21) / \mathrm{RUNX} 1-\mathrm{RUNX} 1 \mathrm{~T} 1 \\
\text { - } & \text { inv(16) or } \mathrm{t}(16 ; 16) / C B F B-M Y H 11 \\
\text { - } & \text { Mutated NPM1 without FLT3-ITD } \\
\text { - } & \text { or with FLT3-ITD low * } \\
\text { - } & \text { Biallelic mutated CEBPA }\end{array}$ \\
\hline Intermediate & $\begin{array}{ll}\text { - } & \text { Mutated NPM1 and FLT3-ITD high * } \\
\text { - } & \text { Wild-type NPM1 without FLT3-ITD or with FLT3-ITD low * } \\
\text { - } & \mathrm{t}(9 ; 11) / \text { MLLT3-KMT2A } \\
\text { - } & \text { Cytogenetic abnormalities not classified as favorable or adverse }\end{array}$ \\
\hline Adverse & $\begin{array}{ll}\text { - } & \mathrm{t}(6 ; 9) / \text { DEK-NUP214 } \\
\text { - } & \mathrm{t}(\mathrm{v} ; 11 \mathrm{q} 23.3) / K M T 2 A \text { rearranged } \\
\text { - } & \mathrm{t}(9 ; 22) / B C R-A B L 1 \\
\text { - } & \text { inv(3) or } \mathrm{t}(3 ; 3) / G A T A 2, M E C O M(E V I 1) \\
\text { - } & \text { Complex karyotype } \\
\text { - } & \text { Monosomal karyotype } \\
\text { - } & \text { Wild-type NPM1 and FLT3-ITD } \text { high * } \\
\text { - } & \text { Mutated RUNX1 T } \\
\text { - } & \text { Mutated ASXL1T } \\
\text { - } & \text { Mutated TP53 }\end{array}$ \\
\hline
\end{tabular}

* Low , low allelic ratio $(<0.5)$; high, high allelic ratio $(>0.5)$; $\uparrow$ these mutations should not be used as an adverse prognostic marker if they co-occur with favorable-risk AML subtypes.

\section{Zebrafish: Characteristics and Relevance to Human Blood Malignancies}

Danio rerio, commonly known as Zebrafish, shares genetic and molecular mechanisms of hematopoiesis with humans [15]. This model offers many advantages, including low-cost, optically transparent embryos, high fecundity, rapid embryogenesis, and short gestation time. The genome editing in zebrafish was known since 1970s, when the first transgenic zebrafish was generated by inserting naked linear DNA [16]. Since then, the genetic manipulation of this model evolved to include clustered regularly interspaced short palindromic repeats (CRISPR) technology [17], which renders zebrafish an attractive model for studying specific gene involvement and for drug screening in blood malignancies [18-20].

During normal zebrafish hematopoiesis, both the primitive and definitive waves arise from the mesoderm germ layer under the control of the Transforming Growth Factor beta (TGF- $\beta$ ) superfamily proteins, known as bone morphogenic proteins (BMP such as bmp2b and bmp7) [21-23]. The generated transient primitive erythroid and myeloid cells are essential for the embryonic development, while the hematopoietic stem cells (HSCs) and progenitor cells (HSPCs) produce blood lineages in the adult fish [24]. In the below section, we will provide an overview of AML models of Zebrafish (summarized in Table 2). 


\subsection{AML Models of Zebrafish}

\subsubsection{Spi-1: MYST3/NCOA2-EGFP}

MYST3 (MOZ) is a member of the MOZ, YBF2, SAS2, TIP60 (MYST) family of histone acetyl-transferases (HAT), while NCOA2 (TIF2) is a member of the p160 HAT family [25-28]. The first AML model in Zebrafish was created by expressing the fusion protein, MYST3/NCOA2 (MOZ/TIF2). This fusion targets hematopoietic cells under the control of spi-1 (pu.1), an early myeloid promoter [29]. pu.1 is an ETS-domain transcription factor expressed in both immature lymphoid/hematopoietic cells and myeloid cells during zebrafish hematopoiesis [30]. Cells expressing pu.1 differentiate into myeloid progeny, whereas cells with low pu.1 expression shift to the erythroid fate [31]. After an extended latent period, a small percentage of transgenic fish developed AML [29]. These animals presented with an extensive invasion of kidneys by myeloid blast cells, proving the oncogenic potency of MYST3/NCOA2 fusion gene [29]. Although this model is useful as a chemical library screen, especially for compounds that target epigenetic regulation of gene expression [29], the long latency and low incidence waned the enthusiasm for its use.

\subsection{2. hsp70: AML1-ETO}

A chromosomal translocation between chromosomes 8 and 21 ( $t(8 ; 21)(q 22 ; q 22))$ occurs in 12-15\% of AML patients [32]. This chromosomal rearrangement yields a fusion transcription factor encoding AML1 (RUNX1) linked to ETO, forming the AML1-ETO fusion product [33-35]. This translocation was introduced under the control of the heat shock promoter $h s p 70$ in zebrafish embryos (hsp70: AML1-ETO). Transgenic Zebrafish recapitulated the human AML features, at both the cytological and transcriptional levels [36]. The expression of this fusion protein led to the accumulation of non-circulating hematopoietic cells, whereby the intermediate cell mass was enriched with myeloperoxidase positive neutrophils and morphologically immature hematopoietic blasts [36]. The disruption of definitive hematopoiesis led to switching the cells fate from the erythroid to the myeloid lineage [36]. Overexpression of the transcription factor reversed the observed phenotypes, implicating scl, as major player downstream of AML1-ETO [36]. This model enabled the screening of a small molecule library and discovery of compounds that antagonize the activity of AML1-ETO in the hematopoietic progenitor cells (HPCs) [36]. Inhibition of COX-2 and $\beta$-catenin signaling antagonized AML1-ETOs effects on HPCs differentiation and may have implications in human AML [37].

\subsubsection{MYCN: HSE: EGFP}

MYCN (N-myc) proto-oncogene is upregulated in many types of hematological malignancies $[38,39]$ including 20 to $40 \%$ of pediatric AML patients [40]. To unravel the molecular and transcriptional networks by which MYCN induces malignancy, Shen et al. established a transgenic embryonic zebrafish model, $\operatorname{Tg}$ (MYCN: HSE: EGFP), expressing the murine MYCN under a heat shock promoter [41]. MYCN overexpression induced immature myeloid blast cell expansion and reprogrammed the hematopoietic cell fate through MYCN downstream-regulated gene $1 \mathrm{~b}$ (ndrg1b) and other lineage-specific hematopoietic transcription factors regulation [41]. The primitive hematopoiesis was enhanced through scl and lmo2 upregulation. Furthermore, erythroid differentiation was blocked through downregulation of gata1, while myelopoiesis was promoted by pu.1 overexpression [41]. This model presents a high AML incidence ( $\sim 75 \%$ of transgenic zebrafish) and a rapid onset occurrence, providing a platform for whole-organism chemical suppressor screens, to identify compounds that can reverse MYCN function in vivo [41].

\subsubsection{FLT3-ITD and NPM1c+ Models in Zebrafish}

FLT3-ITD and NPM1 are two major players in defining the prognosis and response to treatment in AML patients. FLT3 is a tyrosine kinase receptor that plays a major role in hematopoiesis through the regulation of proliferation, differentiation, and apoptosis of HPCs [42]. It is highly expressed on 
leukemic blasts of $70-100 \%$ of AML patients [43,44]. Several mutations occur in the FLT3 receptor, the most common of which leads to an internal tandem duplication (ITD) [45]. FLT3-ITD occurs in 20\% of AML patients and is strongly associated with poor prognosis [46,47]. NPM1, a shuttling protein between the nucleoplasm and the cytoplasm, plays several roles, notably ribosomal biogenesis $[48,49]$. NPM1 is mutated (NPM1c+) in around 30\% of AML patients with normal karyotype [50]. NPM1c+ is continuously translocated to the cytoplasm contributing to leukemogenesis [50].

FLT3-ITD plays a role in embryonic primitive and definitive hematopoiesis in zebrafish. Transgenic zebrafish embryos with human FLT3-ITD showed expansion and clustering of myeloid cells [51]. Thus far, the impact of FLT3-ITD on adult zebrafish remains underexplored.

Bolli et al. generated a transgenic zebrafish model expressing NPM1c+, which perturbed primitive hematopoiesis by promoting the early expansion of pu.1+ myeloid cells [52]. This phenotype was even more pronounced in a p53-deficient background [52]. An increase in the number of gata1+/lmo2 indicating expansion of erythro-myeloid progenitors (EMPs) was also observed. These EMPs highly expressed both c-myb and CD41 but not RUNX1, suggesting a disruption of definitive hematopoiesis where these cells could be the main target of NPM1c+. This model provides a tractable in vivo system for the study of the mechanisms through which hematopoietic development is perturbed in the presence of NPM1c+ [52].

Transgenic zebrafish models expressing either human FLT3-ITD or NPM1 proteins under the control of pu.1 promoter were also generated [53]. For that purpose, spi-1: FLT3-ITD-2A-EGFP/CG2 expressing mutant FTL3-ITD and spi-1: NPM1-Mut-PA/CG2 expressing mutant NPM1 constructs were designed. This double mutant transgenic fish (FLT3-ITD/NPM1.Mut) exhibited an accelerated rate of myeloid leukemogenesis [53]. By the age of six months, around $66 \%$ of the transgenic fish produced significantly increased precursor cells in the kidney marrow along with dedifferentiated myeloid blasts [53].

\subsubsection{Spi-1: CREB-EGFP}

The cAMP response element binding protein (CREB) plays a major role in hematopoiesis through the regulation of proliferation and differentiation of myeloid progenitor cells [54]. Overexpression of CREB is associated with immortalization, growth factor-independent proliferation and blast-like phenotype in BM progenitor cells [55]. CREB is highly expressed in BM samples of both adult and pediatric AML patients [56]. Tregnago et al. generated a transgenic zebrafish model (spi-1: CREB-EGFP) expressing the CREB gene downstream pu.1 promoter in the myeloid cell lineage. CREB overexpression resulted in upregulation of erythroid and myeloid genes, altering primitive hematopoiesis. Among adult transgenic zebrafish, $80 \%$ of the fish developed AML after 9-14 months through the blockage of myeloid differentiation [57]. These fish showed aberrant expression of a set of 20 genes in common with pediatric AML. The most intriguing is the CCAAT-enhancer-binding-protein- $\delta(C / E B P \delta)$ that acts downstream CREB. It resulted in impaired myeloid differentiation that could be reversed through inhibition of the CREB-C/EBP $\delta$ axis. These findings are complementary with the data obtained by screening for CREB and C/EBP $\delta$ in pediatric AML patients, offering an opportunity to test for novel therapeutics through this model [57].

\subsubsection{Spi-1: SOX4-EGFP}

SOX4 is a transcription factor belonging to the SOX (Sry-related high-mobility groupbox) family [58]. In AML patients, SOX4 overexpression results in poor prognosis and short overall survival [59]. SOX4 was reported to contribute to the leukemic phenotype of C/EBP $\alpha$ mutant AML in murine models as well as in human AML. C/EBP $\alpha$ protein typically inhibits the self-renewal of leukemic cells and restores cellular differentiation. SOX4 overexpression results in C/EBP $\alpha$ inactivation, enabling leukemic cells proliferation and AML development [60,61].

Lu et al. generated a transgenic zebrafish model Tg (spi-1:SOX4-EGFP) expressing SOX4 protein downstream the spi-1 myeloid promoter. Early developmental stages of transgenic zebrafish did not 
reveal a difference of expression of SOX4. However, by the age of five months, Tg (spi-1:SOX4-EGFP) zebrafish kidneys started showing mild vacuoles in the renal tubule which evolved into effacement, distorted structure, and increased infiltration of myeloid cells by the ages of 9 and 12 months. A higher number of myeloid progenitor cells and excess blast cells with focal aggregation were observed in the kidney marrow blood cells of 9-, 12-, and 15-months old fish but not younger ones, highlighting that myeloid transformation is age-dependent [59].

\subsubsection{IDH $1 / 2$ Mutation}

Mutations identified in a family of enzymes involved in the citric acid cycle, isocitrate dehydrogenases $1 / 2$ (IDH1/2), account for $16 \%$ of AML patients [62]. These mutations substitute arginine residue almost exclusively at codon 132 in IDH1 (IDH1-R132H) and codons 140 and 172 in IDH2 [62]. To study the involvement of IDH in AML, zidh1 was either suppressed or deleted and resulted in the blockage of differentiation and accumulation of early myeloid progenitor cells, while decreasing macrophage and natural killer progenitor cells [63]. The importance of IDH1 mutation was asserted when plasmids of IDH1-R132H were injected into zebrafish embryos [63]. An increase in 2-hydroxyglutarate (2-HG) level, a reduction of 5-Hydroxymethylcytotsine (5-hmC), and an expansion of myelopoiesis were obtained in these embryos. A human IDH1-R132H-specific inhibitor significantly ameliorated both hematopoietic and 2-HG responses in human but not zebrafish IDH1 mutant expression [63]. This result is not surprising and highlights some of the drawbacks using Zebrafish as a model for human diseases. On the other hand, studies on zidh2 were restricted to the regulation of embryonic hematopoiesis in zebrafish but with no relevance to the human AML [63].

Even with the drawbacks of not possessing many mammalian-like organs, zebrafish still provides an excellent, affordable, and rapid platform for evaluating several aspects of AML. The variations in the biological microenvironment might impede drug delivery and performance in humans. Additionally, zebrafish are ectothermic (cold-blooded), so their physiology is not identical to humans, which might affect enzyme kinetics and metabolism. The genetic diversity detected between individual zebrafish belonging to the same strain confounds data and could be misleading [64]. The sparsity of reagents to study zebrafish at the molecular level is contrasted by the abundance of mouse-specific reagents.

\section{Rodent Models}

Due to the complexity and heterogeneity of AML in humans, rodent models have been instrumental in providing a platform for answering pivotal questions related to AML pathogenesis, disease progression, and developing new effective therapeutic approaches. Among these models, rats and mice represent the closest accepted mammalian models to AML.

\subsection{Rats}

Several transplantable leukemia rat models were established using carcinogens, radiations, and pollutants [65-67].

\section{Transplantable Rat Models}

Acute Myeloid Leukemia/ Chronic Meylogenous Leukemia (AML/CML) leukemia: Repeated intravenous injections of 7, 12-dimethylbenz (a) anthracene (DMBA) into WOP/H-Onc strain or Wistar/H-Onc strain, induced leukemia in $10 \%$ of the rats in 5-9 months. This leukemia has myeloid characteristics as revealed by hematological and histological examination, as well as infiltration of myeloid blasts into several organs (BM, liver, spleen, and lymph nodes). This myeloid nature showed similarities with both human CML (as demonstrated by high peroxidase and Sudan black B positive cells and reduction in alkaline phosphatase positivity) and human AML (non-specific esterase activity, highly reduced in the peripheral blood but slightly reduced in BM). These findings do not support the use of these rats as an exclusive AML model [68]. 
Brown Norwegian Myelogenous Leukemia (BNML): The transplantable promyelocytic leukemia in BN rat (BNML) was first described in 1971. This slow growing leukemia shares many common characteristics with AML, including the disappearance of normal hematopoiesis [69]. Similarities in in vitro colony forming assays between AML patients and BNML rats validated it as a model for AML $[70,71]$. Several therapeutic modalities were optimized using this model; these include the combination of anthracyclines, [72,73] Ara-C, [74,75], 4'-(9-acridinylamino) methanesulfon-m-anisidide (AMSA) [76], and other therapeutics [77-79]. One of the most significant advantages in the BNML model is its contribution to the improvement of minimal residual disease (MRD) detection by karyotyping [80] and multidimensional flow cytometry $[81,82]$.

\subsection{Mice}

Mice offer an invaluable model due to their small size, cost-effectiveness, and easy maintenance, availability of research tools, and ease of manipulation to produce and recapitulate several human diseases, including cancer. Since hematopoiesis in mice has been well characterized, they provide a reasonably reproducible model to study AML pathogenesis and potential therapies. Murine AML models include induced, transgenic animals, and humanized mouse models (Table 3) among others.

\subsubsection{Chemically-Induced Model}

AML models were generated using the L1210 and p388 cell lines, isolated from DBA/2 mice chemically exposed to the carcinogen 3-methylcholantrene [83]. These models were transplantable and provided a platform for testing chemotherapeutic drugs, studying their kinetics, and evaluating their anti-leukemic effectiveness [84]. The L1210 model was used to screen anthracyclines [85] and antimetabolites [86,87] including Cytarabine [88]. The p388 model was used to investigate the efficacy of natural products as topoisomerase II inhibitors [89]. These models allowed significant improvement in the treatment of AML, including the currently used Cytarabine [90]. The main limitation of using these animal models is the induction of more lymphoid than myeloid leukemia, and the needed prolonged exposure to those carcinogens to develop leukemia [91].

\subsubsection{Radiation-Induced Model}

The correlation between radiation and leukemia was established in patients exposed to x-rays, and survivors of nuclear attacks. Among this cohort of subjects, children presented mostly with ALL, whereas adults were more prone to CML and AML [92-95]. All established radiation-induced AML models carry deletions on chromosome 2, where the hematopoietic transcription factor Sfpi1/pu.1 is located [96].

\section{RF Model}

The RF strain was developed by Furth in 1933 at the Rockefeller Institute [97]. In this model, myeloid leukemia was developed following exposure to fission neutron irradiation or gamma irradiation [98]. In the RF model, a single dose of ionizing radiation-induced myeloid leukemogenesis in 4-6 months, with symptoms reminiscent to human AML [99]. Flt3-ITD mutations were identified in $10 \%$ of RF mice [100], which correlates with the occurrence of this mutation in human AML [101].

\section{SJL/J Model}

This model is characterized by high spontaneous frequency of reticulum cell neoplasm type B at an early age [102]. The radiation-induced AML in this model is similar to the secondary human AML occurring after irradiation of Hodgkin disease patients [103]. The efficient development of AML required the addition of promoting factors, such as corticosteroids and growth factors, colony stimulating factor CSF-1, known to be high in AML patients [104]. 


\section{$\mathrm{C} 3 \mathrm{H} / \mathrm{He}$ and CBA Models (CBA/Ca, CBA/Cne, and CBA/H)}

These models were generated in 1920, by cross-breeding Bragg albino with DBA mice. While $\mathrm{C} 3 \mathrm{H} / \mathrm{He}$ was specifically selected for the high incidence of mammary tumors [105], CBA was selected for a lower incidence of mammary tumors. The $\mathrm{C} 3 \mathrm{H} / \mathrm{He}$ was detected $24 \mathrm{~h}$ after irradiation in $\mathrm{BM}$ cells; this indicates that chromosomal 2 alteration is responsible for the initiation of myeloid leukemogenesis [106]. CBA showed chromosome 2 and 4 aberrations [107,108]. Moreover, an 8\% decrease in DNA methylation was observed after exposure to radiation. This hypomethylation played a role in leukemogenesis [109]. The CBA model is considered the most favorable model in radiation-inducedAML because of low spontaneous leukemia incidence (0.1 to $1 \%)$, high incidence of AML after exposure to radiation or benzene, with lower latency, compared to other models, and more importantly, it mimics human AML at the cytological, histopathological, and molecular levels.

\subsubsection{Virally Induced Leukemia Models}

Murine leukemia viruses (MuLV) induce non-B and non-T cell leukemia in mice [110,111] and are considered among the simplest retroviruses that shed light on the pathogenesis of leukemia [112,113]. A model was created by injecting cell-free filtrates, including replication-deficient spleen focus forming virus (SFFV) and a replication-competent Friend MuLV [114,115]. It was noticed that the same infection of MuLV induces several subtypes of AML (Table 4), resembling French-American-British (FAB) classification of human AML [116]. Furthermore, MuLV-induced AML led to the discovery of several genes with a significant role in the regulation of growth, death, lineage determination, and development of hematopoietic precursor cells [117]. MuLV induced AML is considered a critical landmark for understanding the pathogenesis of human AML, since it unraveled relevant unknown oncogenes to leukemogenesis (Table 4).

\subsubsection{Transposon Models}

Sleeping Beauty (SB) transposon is an insertional mutagenesis system, allowing overexpression or inactivation of specific genes depending on the transposon orientation and integration site $[118,119]$. $\mathrm{SB}$ consists of a mobilized piece of DNA, transposon, and a transposase enzyme [120]. In a transgenic animal with a humanized NPM1c+ knock-in allele, this system enhanced the incidence and onset of AML in NPM1c+ mice [121]. An advantage of this model was the identification of mutations in leukemia genes [121].

\subsubsection{Transgenic Models: Single Mutation}

\section{PML-RAR $\alpha \mathrm{t}(15 ; 17)$}

Acute promyelocytic leukemia (APL) is a subtype of AML, characterized by $t(15 ; 17)$ chromosomal translocation, resulting in the promyelocytic leukemia-retinoic acid receptor $\alpha$ (PML-RAR $\alpha$ ) fusion protein [122,123]. PML-RAR $\alpha$ was expressed in three mouse models under the myeloid regulatory promoters. Under the $C D 11 b$ promoter, transgenic mice showed abnormal myelopoiesis and increased radiation sensitivity, however, did not develop any leukemia [124]. Mice expressing the transgene under the human cathepsin G (HCG) and human MRP8 (hMRP8) promoters [124-126] developed APL phenotypes after a long period of latency $[125,126]$. These two models recapitulated the remissions seen after all trans-retinoic acid (ATRA) treatment in human APL [125,126].

\section{AML1-Eight-Twenty One Oncoprotein}

AML1-Eight-Twenty One oncoprotein (ETO) chimeric product, encoded by the $t(8 ; 21)$, occurs in around $12-15 \%$ of AML [32]. Knock-in mice expressing AML1-ETO is embryonic lethal due to the complete absence of liver-derived definitive hematopoiesis $[127,128]$. Embryonic livers contained dysplastic multilineage hematopoietic progenitors that had an abnormally high self-renewal 
capacity in vitro, a phenotype typical of leukemic cells [129]. To bypass the embryonic lethality, inducible transgenic models were generated. These mice expressed AML1-ETO in their BM progenitor cells $[130,131]$. Although abnormal maturation and proliferation of progenitor cells were observed, mice failed to develop leukemia [130,131]. Expression of AML1-ETO under the control of $h M R P 8$ promoter was unable to develop AML until their exposure to a robust DNA-alkylating mutagen, $N$-ethyl- $N$-nitrosourea [132]. To further enhance AML development, this mouse model was modified by either the expression of other factors or mutations in tyrosine kinases such as c-KIT, FLT3-ITD, or the TEL- platelet-derived growth factor receptor $\beta$ (PDGFbR) $[133,134]$.

\section{CBFB-MYH11}

The beta subunit of the core binding complex $(\mathrm{CBFB})$ is a heterodimeric core-binding transcription factor, with a critical role in hematopoiesis [135]. CBF products, due to chromosomal translocations, account for approximately $25 \%$ of pediatric and $15 \%$ of adult AML patients [136]. The translocation $\operatorname{Inv}(16)(\mathrm{p} 13 ; \mathrm{q} 22)$ is a result of the binding of CBFB subunit to the tail region of the smooth muscle myosin heavy chain (SMMHC) gene, MYH11 [137]. The resulting fusion protein (CBFB-MYH11) competes with the binding of $\mathrm{CBF}$ to target genes, disrupting transcriptional regulation, thus contributing to leukemic transformation [137]. Similar to embryos with homozygous mutations in AML1 [128], knock-in embryonic mice ( $\left.C b f b^{+/ C b f b-M Y H 11}\right)$ lacked definitive hematopoiesis and died during gestation [138]. Chemically or retrovirally induced mutations in heterozygous CBFB-MYH11 adults led to AML development $[138,139]$. A conditional knock-in mouse model expressing CBFB-MYH11 fusion protein in adult mice $\left(C b f b^{+/ 56 M}\right)$ was also generated [140] and led to AML development in $90 \%$ of the mice within five months [140].

Mutant Nucleophosmin-1 (NPM1c+)

Mutations in the Nucleophosmin-1 (NPM1) gene represent one of the most frequent genetic aberrations in AML [141] and account for 30\% of AML patients [50]. Transgenic mice harboring the NPM1c+ mutation developed myeloproliferation in BM and spleen, supporting a role of NPM1c+ in AML [142]. Chou et al. generated a knock-in transgenic mouse model by inserting the most frequent mutation, TCTG called mutation A, in the C-terminus of wt-NPM1 [143]. Mice homozygous for the transgene encountered embryonic lethality, whereas one-third of the heterozygotes $(\mathrm{Npm} 1 \mathrm{wt} / \mathrm{C}+)$ developed the fetal myeloproliferative disease but not AML [143]. Conditional expression of NPM1c+ with further genetic manipulations resulted in two models [121,144]. In one model, one-third of the transgenic mice developed leukemia after a long period of latency associated with AML features [144]. In the other model, the expression of humanized NPM1c+ in the hematopoietic stem cells caused HOX overexpression, enhanced self-renewal, and expanded myelopoiesis [121].

Fms-Related Tyrosine Kinase 3 Internal Tandem Repeats

The second most common genetic aberrations in de novo AML patients occur in the fms-related tyrosine kinase 3 internal tandem repeats (FLT3-ITD) gene on chromosome 13. These associate with poor prognosis and short overall survival (OS) [145]. A transgenic mouse model expressing FLT3-ITD under the vav hematopoietic promoter was created [146]. The majority of transgenic mice developed a myeloproliferative syndrome (MPS) characterized by megakaryocytic hyperplasia and thrombocytosis but not AML [146]. In FLT3-ITD knock-in mice, loss of FLT3 wild-type allele contributed to myeloid expansion and aggressiveness of the MPS disease [147]. Several other models expressing this mutation also revealed MPS but not AML [148,149].

Mixed Lineage Leukemia (MLL)

The translocation $t(9 ; 11)(p 22 ; q 23)$ produces the fusion product MLL-AF9 $[150,151]$. In one model, embryonic stem cells were generated from an in-frame fusion of AF9 with exon 8 of mouse MLL [152]. Other models conditionally expressed MLL-AF9 [153]. These models developed only 
AML despite the widespread activity of the MLL promoter $[152,153]$. Conditional expression of MLL-AF9 in long-term hematopoietic stem cells (LT-HSC) produced aggressive AML with extensive tissue infiltration, chemo-resistance, and expressed genes related to epithelial-mesenchymal transition in solid cancers [154]. MLL early introduction results in abnormalities of myeloid cell proliferation and differentiation [155]. Moreover, HOXa9 was found to be essential for the MLL-dependent leukemogenesis in vivo [156].

The translocation $\mathrm{t}(4 ; 11)(\mathrm{q} 21 ; \mathrm{q} 23)$ produces the fusion product MLL-AF4. This translocation is associated with pro-B-ALL and rarely AML [157]. Although several models have been established for this translocation, only few models resulted in AML. MLL-AF4 models generated using both a knock-in [158] and Cre-inducible invertor model [159] produced large B-cell lymphoma rather than the immature acute leukemia observed in humans $[158,159]$. The MLL-AF4 expression in hematopoietic precursors, during mouse embryonic development, developed long latency B-cell lymphoma [159,160]. Furthermore, MLL-AF4 knock-in followed by in vitro inducible transduction generated mice with both AML and pre-B-ALL as well as a few MLLs [161].

Leukemia with the $t(11 ; 19)$ (q23;p13.3) translocation express MLL-ENL fusion proteins capable of malignant transformation of myeloid and/or lymphoid progenitor(s). Immortalized cells containing MLL-ENL proviral DNA or enriched primary hematopoietic stem cells transduced with MLL-ENL induced myeloid leukemia in syngeneic and SCID recipients [162]. Using an in vitro B-cell differentiation system, retroviral transduction of MLL-ENL generated a leukemia reminiscent of human MLL-ENL ALL [163]. Other models expressed MLL-ENL-ERTm, the ligand-binding domain of the estrogen receptor modified to specifically recognize synthetic but not endogenous estrogens, using retroviral transduction approach [164]. Several other models were generated encountering more mutation along with MLL-ENL [165,166].

\section{IDH $1 / 2$}

A conditional knock-in mouse model was created by inserting the mutated human IDH1 (R132H) into the endogenous murine idh1 locus. IDH1 (R132H) was expressed in all hematopoietic cells under the vav promoter (vav-KI mice) or specifically in cells of the myeloid lineage (LysM-KI mice) [167]. Transgenic mice showed increased number of early hematopoietic progenitors and developed splenomegaly and anemia with extramedullary hematopoiesis, characteristics of a dysfunctional BM niche, along with partial blockage in myeloid differentiation [167]. Moreover, LysM-KI cells have hypermethylated histones and changes to DNA methylation similar to those observed in human IDH1or IDH2-mutant AML, demonstrating the induction of leukemic DNA methylation signature in the mouse model [167].

\subsubsection{Transgenic Models: Compound Transgenic Mouse Models}

\section{K-RAS-G12D + PML-RAR $\alpha$}

$4 \%$ and $10 \%$ of APL patients with PML-RAR $\alpha$ fusion had oncogenic N-RAS and K-RAS mutations, respectively $[168,169]$. The conditional expression of oncogenic K-RAS and PML-RAR $\alpha$ in mice induced a rapid-onset and highly penetrant, lethal APL-like disease [170].

These mice may be used to test for the therapeutic efficacy of inhibitors of RAS post-translational modifications and RAS downstream signaling [170].

N-RASD12 + BCL-2

N-RAS, a protein belonging to the family of RAS GTP-ases, is mutated in patients at risk of leukemic transformation after chemotherapy and/or radiotherapy [171]. N-RAS mutation at codon 12 is the most frequent abnormality in myelodysplastic syndromes (MDS), associated with AML transformation and poor OS [172]. B-cell lymphoma 2 (BCL-2) protein is an apoptosis regulatory protein. BCL-2 is overexpressed in AML patients [173], which blocks the differentiation of myeloid 
progenitors [174]. Both mutants have been previously identified as risk factors for AML in MDS patients [172].

Two murine models of initiation and progression of human MDS/AML were generated [175]. The transplantable model expressing hBCL-2 in a primitive compartment by mouse mammary tumor virus-long terminal repeat (MMTVtTA /TBCL-2/NRASD12) represents human MDS, whereas the constitutive MRP8 [BCL-2/NRASD12] model is closer to AML [175]. Both models showed expanded leukemic stem cell $\left(\mathrm{Lin}^{-} / \mathrm{Sca}-1^{+} / \mathrm{c}-\mathrm{Kit}^{+}\right)$populations. $\mathrm{hBCL}-2$ is observed in the increased RAS-GTP complex within the expanded Sca- $1^{+}$compartment [175]. The difference of hBCL-2 oncogenic compartmentalization associates with the pro-apoptotic mechanisms in MDS and the anti-apoptotic in AML mice [175]. Downregulation of hBCL-2 in MDS mice partially reversed the phenotype and prolonged survival; however BM blasts and tissue infiltration persisted [175]. This model revealed that the two candidate oncogenes $B C L-2$ and mutant $N-R A S$ can cooperate to give rise to malignant disease with a penetrance of around $80 \%$ and a latency period of 3 to 6 months [175].

Mixed Lineage Leukemia-Partial Tandem Duplication + FLT3-ITD

Mixed lineage leukemia-partial tandem duplication (MLL-PTD) is expressed in 5 to $7 \%$ of cytogenetically normal (CN)-AML patients [176,177]. Approximately $25 \%$ of these patients have constitutive activation of FLT3-ITD, conferring a poor prognosis [178]. To recapitulate the $M l l^{P T D / W T}: f l t 3^{I T D / W T}$ AML found in humans, a double knock-in mouse model was generated by expressing these two mutated genes under their respective endogenous promoters [179]. After a period of latency, this model developed AML with a short life span, extensive extramedullary involvement, and increased aggressiveness [179]. Reminiscent of this subtype of AML in humans, these transgenic mice have normal chromosomal structures, reduced MLL-WT expression, loss of FLT3-WT, and increased total FLT3 expression [179-182]. Moreover, increased HOXA9 transcript levels were observed, rendering this model valuable for the assessment of epigenetic modifying agents combined with tyrosine kinase inhibitors [179].

\section{NUP98-HOXD13 + FLT3-ITD}

The chromosomal translocation $\mathrm{t}(2 ; 11)$ (q31;p15) leads to the fusion of Nucleoporin (NUP98), a structural component of the nuclear pore complex, to the homeobox protein NHD13 (HOXD13), inducing leukemogenesis [183]. NUP98-HOX fusions are observed in human and murine MDS [184]. Clinical and experimental evidence demonstrated that high rate of FLT3-ITD mutations was observed in patients with NUP98 translocations [185]. High-level transcriptional expression of NUP98-HOX correlated with higher transcript levels of FLT3 and an increased incidence of FLT3 activating mutations [185]. A novel model combining an FLT3-ITD mutation with NHD13 (HOXD13) was generated using their respective endogenous promoters [186]. Initially, these transgenic mice developed leukemia with both primitive myeloid and lymphoid origin. Later, strictly myeloid leukemia with minimal differentiation were monitored [186]. Indeed, NHD13 transgene enhanced the overexpression of the HOX genes, HOXA7, HOXA9, HOXB4, HOXB6, HOXB7, HOXC4, and HOXC6 [186], shown to play an important role in HSC self-renewal and are upregulated in acute leukemia [187-189]. Nevertheless, mice encountered a spontaneous loss of heterozygosity with a high frequency, resulting in the loss of WT FLT3 allele, [186], a characteristic of patients with FLT3-ITD mutations [180]. These transgenic mice provide a model to study the molecular pathways underlying MDS-related AML [186].

\section{NPM1c+/FLT3}

NPM1c+ and FLT3-ITD double mutations are found in about 40\% of AML patients [190]. A compound transgenic mouse model with a double mutation in NPM1 and FLT3 was generated by crossing conditional $\mathrm{Npm}^{\text {flox-cA/+ }}$ with constitutive $\mathrm{Flt}^{\mathrm{ITD} /+}$ mice [191]. Inducing recombination of $N p m 1^{f l o x-c A}$ in hematopoietic stem cells was accomplished by crossing the double heterozygous mice into Mx1-Cre transgenic mice [191]. Double mutant mice developed AML and died by the age of 31-68 days. Peripheral blood showed increased leukocyte counts, reduced numbers of circulating 
B and T lymphocytes along with a marked population of immature blasts, while BM cells exhibited increased self-renewal potential [191]. Solid organs were infiltrated with abnormal myeloid cells inducing splenomegaly and hepatomegaly by the time of death, highlighting the role of this double mutation in leukemogenesis [191].

\section{N-RAS-G12D + CBFB-MYH11}

A knock-in mice (Nras ${ }^{L S L-G 12 D} ; C b f b^{56 M}$ ) with an allelic expression of oncogenic N-RAS ${ }^{G 12 D}$ and CBFB-MYH11 developed leukemia in a cell-autonomous manner, with a short median latency and high leukemia-initiating cell activity [192]. Mice displayed an increased survival of pre-leukemic short-term HSCs and myeloid progenitor cells with a sustained blocked differentiation induced by the fusion protein [192]. Nras ${ }^{L S L-G 12 D} ; C b f b^{56 M}$ leukemic cells were sensitive to pharmacologic inhibition of the MEK/ERK signaling pathway [192], highlighting the importance of this pathway in AML and proposing MEK inhibitors as potential therapeutic agents in inv16/ N-RAS G12D AML [192].

\section{NPM1c + N-RAS-G12D}

One of the most common mutations with NPM1c+ is the N-RAS mutation occurring in $20 \%$ of NPM1c+ AML patients [190]. NPM1 and N-RAS double mutant transgenic mice $\left(N p m 1^{c A /+}\right.$; $\mathrm{Nras}^{\mathrm{G} 12 \mathrm{D} /+}$ ) developed high penetrance, enhanced self-renewal capacity in hematopoietic progenitors, and AML-like myeloid differentiation bias [193]. At the genomic level, frequent amplification of the mutant N-RAS-G12D allele was observed, along with other somatic mutations in AML driver genes [193]. Within the HOX genes, which were overexpressed, HOXa genes and downstream targets were crucial for the survival of the double-mutant mice [193].

\section{WT1-R394W + FLT3-ITD}

Wilms tumor 1 (WT1) is a zinc finger transcriptional regulator of target genes implicated in cell differentiation and quiescence [194]. Mutations in WT1 occur in 10-15\% of CN-AML, and it is frequently associated with mutations in several genes [194,195]. FLT3-ITD and WT1 mutations, when present concomitantly, identify a group of AML patients that fail to respond to the standard induction chemotherapy, which results in poor OS $[195,196]$. Double mutant mice Flt3 + ITD $/ W t 1^{+/ R 394 W}$ displayed manifestations of shortened survival, myeloid expansion in the BM, anemia, and erythroid dysplasia [197]. Although this model did not appear sufficient to consistently recapitulate human AML, it demonstrated that the combined mutations resulted in a more aggressive disease than either mutant genotype [197].

\subsubsection{Humanized Models}

Humanized mouse models, injected with AML cell lines or patient-derived AML blasts, offered a faster approach and were instrumental in studying different aspects of AML. Several models were attempted to study AML in Nude mice with little success [198,199]. This section will focus on promising models for AML studies.

\section{SCID Mice}

The severe combined immuno-deficient (SCID) mice lacking B and T cell immunity [200], represent essential humanized AML mouse models [201]. Indeed, patient-derived AML cells engraftment enabled the identification of leukemia-initiating cells (LIC), expressing CD $34^{+}$CD $38^{-}$surface markers, recapitulating the human HSCs signature [202]. Engraftment of AMLs from different FAB classes into SCID mice reflected their intrinsic biologic behavior, suggesting a clinical correlation to the growth and dissemination of these leukemic subtypes [203]. However, lack of species cross-reactivity of cytokines and the innate host immunity against human AML cells resulted in poor engraftment of the BM [204]. In an attempt to overcome these limitations, exogenous human cytokines and growth factors were 
provided, which resulted in better engraftment of human cells [202,204-206]. One limitation of this model is the "leakiness" of the SCID mutation occurring in around $10 \%$ of the mice [207]. These mice present functional $\mathrm{B}$ and $\mathrm{T}$ cells, enhanced natural killer (NK) cell activity, and complement activation decreasing the engraftment efficiency [208]. An attempt to bypass this problem uses radiation and/or anti-asialo-GM1 antibody pretreatment. Unfortunately, it reduced the survival of the host, rendering this model unsuitable for human xenograft $[209,210]$.

\section{NOD/SCID Mice}

To further improve tumor engraftment, a non-obese diabetic (NOD/SCID) model exhibiting further impairment of NK activity, reduced mature macrophage, and total lack of B and T cells was generated [211]. This model yielded higher engraftment rates with fewer human AML cells, yet with preserved morphological, phenotypical, and genotypical characteristics of the AML donors [212-215]. This model was used successfully in the screening for new therapeutics in AML [216]. In addition, human AML cells engraftment enabled the fractionation of LICs (CD34 $\mathrm{CD}^{-}{ }^{-}$) into CD34 ${ }^{+} / \mathrm{CD}^{-} 1^{-} / \mathrm{HLA}-\mathrm{DR}$ [217], CD34 Thy1 hematopoietic stem cells [218] and CD34/CD117 (or ckit) [219] subpopulations. Nevertheless, the NOD/SCID model presents the limitation by which higher engraftment rates required the supplementation of human cytokines or transplantation of growth-factor producing cells $[220,221]$. Moreover, long term engraftments (more than 8.5 months) were disabled due to the development of thymic lymphomas and restoration of NK cells activity during this period [211]. A variant with NOD/SCID background is the NSS model (N/S-S/GM/3) expressing Steel factor (SF), granulocyte macrophage-colony-stimulating factor (GM-CSF) and interleukin-3 (IL-3) human growth factors was generated [222]. NSS displayed enhanced engraftment of pre-leukemic myeloid cell cultures, as well as primary human AML samples, suggesting that the NSS mouse is a better host for at least a subset of AML samples [223].

\section{NSG Mice}

NOD/SCID mice were further immunosuppressed to generate the NOD/SCID b2-microglobulin null mice with a complete abolishment of the NK cell activity [224]. Importantly, a NOD/SCID IL2-R $\gamma^{-/-}$or NSG model was generated by deletion or truncation of the gamma chain of IL-2R [225]. In addition to all the abnormalities of their predecessors, NSG mice possess a defective production of IL-2, IL-4, IL-7, IL-9, IL-15, and IL-21 as well as a severe impairment of the dendritic cell (DC) and their capacity to produce interferon $\gamma($ IFN- $\gamma$ ) upon stimulation $[225,226]$. Engraftment of newborn NSG mice with human $\mathrm{CD} 34^{+} \mathrm{HSC}$ s leads to the generation of a complete hematopoietic system, including red blood cells and platelets [226]. Studies revealed a significantly higher potential of AML cells engraftment in adult NSG mice in comparison to previous immunodeficient hosts [227,228]. Attempts to create different subtypes of AML were successful in NSGs [228]. NSG mice xenotransplanted with five well-characterized AML cell lines established AML models of particular relevance and significance to drug-sensitivity studies [228]. These models were exploited to study the in vivo potency of an Imidazoquinoxalines immunomodulatory drug, EAPB0503, and showed its specific activity in NPM1c+ AML subtype [229]. The usability of NSG model allowed the evaluation of the effect of a synthetic retinoid ST1926, or its encapsulated form in nanoparticles (ST1926-NP). El-Houjeiri et al. demonstrated that ST1926-NP is more potent in NSG injected with THP-1 cells [230]. MOLM-13-injected NSG mice showed strong efficacy to chemotherapy (cytarabine, $50 \mathrm{mg} / \mathrm{kg}$ ) and $5+3$ regimen of daunorubicin $(1.5 \mathrm{mg} / \mathrm{kg})$ [231]. These models enabled the in vivo tracking of UCB-NK cells, demonstrating their capability to migrate to BM and inhibit progression of human leukemia cells. Administering a low dose of human IL-15 enhanced survival of these mice, emphasizing the role of innate immunity in AML outcome [232]. In that sense, utilization of NSG model enabled the assessment of the combination of HSPC-NK cell adoptive transfer with the hypomethylating agents (HMAs), azacitidine (AZA), and decitabine (DAC). Cany et al. signified that the therapeutic combination exerted a significant delay in AML progression in these mice [233]. 
Table 2. A summary of generated AML Zebrafish models and their contribution to the understanding of the disease.

\begin{tabular}{|c|c|c|c|}
\hline Zebrafish Model & Zebrafish Manipulation & Model Features and Major Findings & References \\
\hline spi-1: MYST3/NCOA2-EGFP & $\begin{array}{l}\text { Transgenic expression of human MYST3/NCOA2 fusion under the } \\
\text { spi-1/pu.1 promoter }\end{array}$ & $\begin{array}{l}\text { First AML model in zebrafish } \\
1.1 \% \text { of transgenic fishes expressing the transgene developed AML after } \\
\text { long latency }\end{array}$ & [29] \\
\hline hsp70: AML1-ETO & $\begin{array}{l}\text { Transgenic expression of human AML1-ETO fusion under } h s p 70 \\
\text { promoter }\end{array}$ & $\begin{array}{l}\text { A phenotype similar to human AML } \\
\text { Disruption of definitive hematopoiesis: the switch of cell fates from erythroid } \\
\text { to myeloid through gata1 downregulation and pu.1 overexpression } \\
\text { AML1-ETOs effects on HPCs differentiation was mediated through } \\
\text { Cycloxygenase-2 (COX-2) and } \beta \text {-catenin signaling pathways }\end{array}$ & {$[36,37]$} \\
\hline$m R N A: N P M c+$ & $\begin{array}{l}\text { mRNAs injection into 1-cell-stage embryos followed by morpholinos } \\
\text { (MOs) targeting npm1a and npm1b }\end{array}$ & $\begin{array}{l}\text { Perturbation of primitive and definitive hematopoiesis } \\
\text { Alterations in the expression of major transcription factors (pu.1+, mpx+, } \\
\text { csf1r+, c-myb, CD41, RUNX1) }\end{array}$ & [52] \\
\hline HSE-MYCN-EGFP & Induction of murine $N$-myc gene through heat-shock promoter & $\begin{array}{l}\text { AML development with high incidence and rapid onset } \\
\text { Enhancement of primitive hematopoiesis through alteration of transcription } \\
\text { factors (pu.1, gata1, scl, lmo2, p27kip and p21cip1) } \\
\text { Activation of major cancer signaling pathways }\end{array}$ & [41] \\
\hline \multirow[t]{2}{*}{ IDH1/2 mutants } & $\begin{array}{l}\text { Knockdown of zebrafish } i d h 1 \text { and } i d h 2 \text { (zidh1 and zidh2) by morpholino } \\
\text { knockdown and Transcription activator-like effector nuclease } \\
\text { (TALEN-)mediated mutagenesis }\end{array}$ & $\begin{array}{l}\text { zidh1 suppression/deletion is correlated with a blockage of differentiation of } \\
\text { the myeloid lineage } \\
\text { zidh1 effects definitive hematopoiesis exclusively } \\
\text { zidh } 2 \text { affects primitive hematopoiesis exclusively }\end{array}$ & \multirow[t]{2}{*}{ [63] } \\
\hline & Transgenic expression of human IDH1 mutation & Embryos recapitulated the features of human AML & \\
\hline $\begin{array}{l}\text { FLT3-ITD-2A-EGFP spi-1: } \\
\text { NPM1-Mut-PA spi-1: }\end{array}$ & $\begin{array}{l}\text { Transgenic expression of human FLT3-ITD or/and NPM1 mutations } \\
\text { under the spi-1 promoter }\end{array}$ & $\begin{array}{l}\text { Myeloproliferative neoplasm (MPN) development as a result of a single } \\
\text { mutation. } \\
66.6 \% \text { of double mutant transgenic fish showed increased precursor cells in } \\
\text { the kidney marrow along with dedifferentiated myeloid blasts. }\end{array}$ & [53] \\
\hline spi-1: CREB-EGFP & Expression of $C R E B-E G F P$ under spi-1 promoter in myeloid lineage & $\begin{array}{l}\text { Alteration of primitive hematopoiesis in embryos } \\
\text { AML development in } 79 \% \text { of adult fishes by } 9-14 \text { months } \\
\text { Aberrant expression of } 20 \text { genes diagnosed in pediatric AML }\end{array}$ & [57] \\
\hline Spi-1: SOX4-EGFP & Expression of SOX4 protein downstream the spi-1 promoter & $\begin{array}{l}\text { Increase in the number of myeloid progenitor cells and blast cells in the } \\
\text { kidney marrow } \\
\text { Distortion of the kidney structure }\end{array}$ & [59] \\
\hline
\end{tabular}


Table 3. A summary of generated AML mice models and their contribution to the understanding of the disease.

\begin{tabular}{|c|c|c|c|c|}
\hline \multicolumn{2}{|c|}{ Mouse Model } & Manipulation & Outcomes and Major Findings & References \\
\hline \multicolumn{2}{|l|}{ Chemically-Induced Model } & $\begin{array}{l}\text { Transplantable AML models were generated } \\
\text { using the L1210 and p388 cell lines, isolated } \\
\text { from DBA/2 mice chemically exposed to the } \\
\text { carcinogen 3-methylcholantrene. }\end{array}$ & $\begin{array}{l}\text { Provide a platform for testing } \\
\text { chemotherapeutic drugs, studying their } \\
\text { kinetics, and evaluating their anti-leukemic } \\
\text { effectiveness (mainly Cytarabine) }\end{array}$ & {$[83,84,90]$} \\
\hline \multirow[t]{3}{*}{ Radiation- Induced Model } & RF model & $\begin{array}{l}\text { Myeloid leukemia was developed following } \\
\text { exposure to fission neutron irradiation or } \gamma \\
\text { irradiation }\end{array}$ & $\begin{array}{l}\text { FLT3-ITD mutations were identified in } 10 \% \\
\text { of RF-AML mice which correlates with the } \\
\text { occurrence of mutation of human AML }\end{array}$ & {$[98,100,101]$} \\
\hline & $\mathrm{SJL} / \mathrm{J}$ model & $\begin{array}{l}\text { The radiation induced AML (RI-AML) in } \\
\text { this model, is similar to the secondary } \\
\text { human AML occurring after irradiation of } \\
\text { Hodgkin disease patients }\end{array}$ & $\begin{array}{l}\text { The efficient development of AML in this } \\
\text { model was achieved by adding promoting } \\
\text { factors, corticosteroids and growth factors } \\
\text { like colony stimulating factor CSF-1, known } \\
\text { to be high in AML patients }\end{array}$ & {$[103,104]$} \\
\hline & $\begin{array}{l}\text { C3H/He and CBA models (CBA/Ca, } \\
\text { CBA/Cne, and CBA/H) }\end{array}$ & $\begin{array}{l}\text { These models were generated by cross } \\
\text { breeding Bragg albino with DBA mice }\end{array}$ & $\begin{array}{l}\text { CBA model is considered the most favorable } \\
\text { model in RI-AML } \\
\text { High incidence of AML after exposure to } \\
\text { radiation or benzene with lower latency } \\
\text { compared to other models, } \\
\text { Mimics human AML at the cytological, } \\
\text { histopathological, and molecular levels. }\end{array}$ & {$[107,108,234]$} \\
\hline \multicolumn{2}{|l|}{ Virally-induced leukemia models MuLV } & $\begin{array}{l}\text { Murine leukemia viruses (MuLV) induce } \\
\text { non-B and non-T cell leukemia in mice }\end{array}$ & $\begin{array}{l}\text { Same infection of MuLV induces several } \\
\text { subtypes of AMLthat resembles FAB } \\
\text { classification } \\
\text { Identifies unknown oncogenes contributing } \\
\text { to leukemogenesis. }\end{array}$ & $\begin{array}{c}{[112,113,116,117]+} \\
\text { Table } 2\end{array}$ \\
\hline Transposon models & & $\begin{array}{l}\text { Sleeping Beauty (SB) transposon is another } \\
\text { insertional mutagenesis system, allowing } \\
\text { overexpression or inactivation of specific } \\
\text { genes depending on the transposon } \\
\text { orientation and integration site }\end{array}$ & $\begin{array}{l}\text { Identification of mutations in leukemia } \\
\text { genes, which provided new pathogenetic } \\
\text { insights and potential therapeutic targets in } \\
\text { NPM1c+ AML }\end{array}$ & {$[118,119,121]$} \\
\hline
\end{tabular}


Table 3. Cont.

\begin{tabular}{|c|c|c|c|c|c|}
\hline \multicolumn{3}{|c|}{ Mouse Model } & \multirow{2}{*}{$\begin{array}{l}\text { Manipulation } \\
\begin{array}{l}\text { Expressing PML-RAR } \alpha \\
\text { under CD11b promoter }\end{array}\end{array}$} & \multirow{2}{*}{\begin{tabular}{l}
\multicolumn{1}{c}{ Outcomes and Major Findings } \\
Abnormal myelopoiesis and increased \\
radiation sensitivity \\
No AML development
\end{tabular}} & \multirow{2}{*}{$\begin{array}{c}\text { Reference: } \\
{[124]}\end{array}$} \\
\hline \multirow{9}{*}{$\begin{array}{l}\text { Trans-genic } \\
\text { models }\end{array}$} & \multirow{9}{*}{ Single mutation } & \multirow{3}{*}{$\begin{array}{l}\text { Promyelocytic Leukemia protein } \\
\text { (PML)-RAR } \alpha \text { t(15;17) }\end{array}$} & & & \\
\hline & & & $\begin{array}{l}\text { Expressing PML-RAR } \alpha \text { under human } \\
\text { cathepsin G (HCG) promoter }\end{array}$ & $\begin{array}{l}\text { APL phenotype after long latency period } \\
\text { Remission seen after All Trans Retinoic Acid } \\
\text { (ATRA) treatment in APL }\end{array}$ & [125] \\
\hline & & & $\begin{array}{l}\text { Expressing PML-RAR } \alpha \text { under human MRP8 } \\
\text { (hMRP8) promoter }\end{array}$ & $\begin{array}{l}\text { APL phenotype after long latency period } \\
\text { Remission seen after ATRA treatment in APL }\end{array}$ & [126] \\
\hline & & \multirow{3}{*}{$\begin{array}{l}\text { AML1- Eight-Twenty One } \\
\text { oncoprotein (ETO) }\end{array}$} & $\begin{array}{l}\text { Knock-in of AML1-ETO into mouse embryos } \\
(\text { AML1-ETO/+) }\end{array}$ & $\begin{array}{l}\text { Absence of liver-derived definitive } \\
\text { hematopoiesis } \\
\text { Embryonic lethality }\end{array}$ & {$[127,128]$} \\
\hline & & & $\begin{array}{l}\text { Expressing AML1-ETO in adult bone } \\
\text { marrow progenitor cells }\end{array}$ & $\begin{array}{l}\text { Abnormal maturation and proliferation of } \\
\text { progenitor cells } \\
\text { No AML development }\end{array}$ & {$[130,131]$} \\
\hline & & & $\begin{array}{l}\text { Expressing AML1-ETO under human MRP8 } \\
\text { (hMRP8) promoter }\end{array}$ & $\begin{array}{l}\text { AML development after exposure to } \\
N \text {-ethyl- } N \text {-nitrosourea }\end{array}$ & [132] \\
\hline & & \multirow{2}{*}{ CBFB-MYH11 } & $\begin{array}{l}\text { Knock-in embryonic mice } \\
(\mathrm{Cbfb}+/ \mathrm{Cbfb}-\mathrm{MYH} 11)\end{array}$ & $\begin{array}{l}\text { Lack of definitive hematopoiesis } \\
\text { Embryonic lethality }\end{array}$ & [138] \\
\hline & & & $\begin{array}{l}\text { Chemical/ retroviral mutagens on } \\
\text { heterozygous CBFB-MYH11 adults }\end{array}$ & AML development & {$[138,139]$} \\
\hline & & $\begin{array}{l}\text { Mutant Nucleophosmin-1 } \\
\text { (NPM1c+) }\end{array}$ & $\begin{array}{l}\text { Knock-in mice expressing NPM1 with } \\
\text { mutation A (NPM1c+) }\end{array}$ & $\begin{array}{l}\text { Homozygotes encountered embryonic } \\
\text { lethality } \\
1 / 3 \text { of the heterozygotes }(\mathrm{Npm} 1 w \mathrm{w} / \mathrm{c}+\text { ) } \\
\text { developed fetal myeloproliferative disease } \\
\text { but not AML }\end{array}$ & [143] \\
\hline
\end{tabular}


Table 3. Cont.

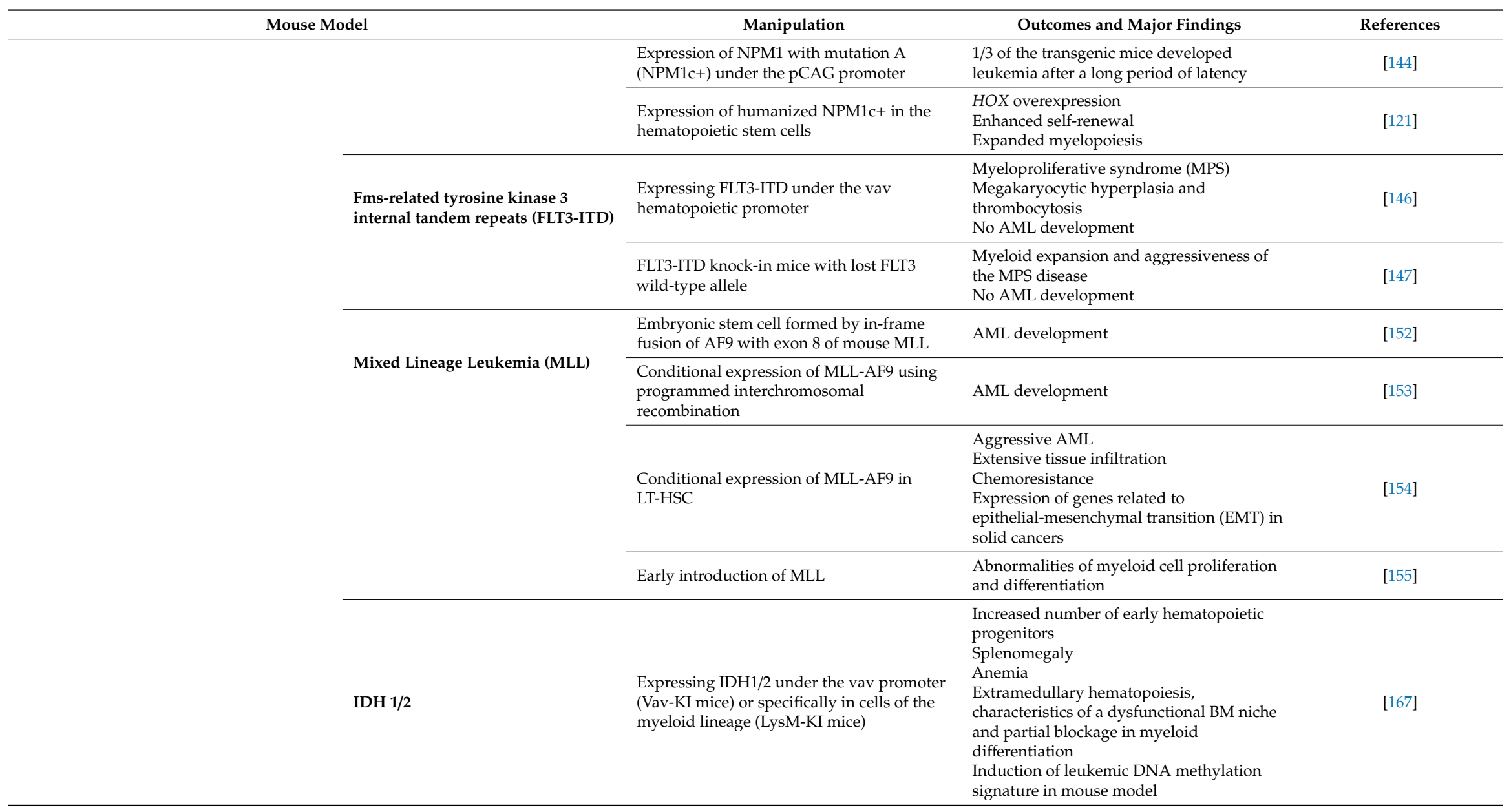


Table 3. Cont.

\begin{tabular}{|c|c|c|c|c|}
\hline \multicolumn{2}{|c|}{ Mouse Model } & Manipulation & Outcomes and Major Findings & References \\
\hline \multirow{6}{*}{ Compound mutations } & K-RAS-G12D + PML-RAR $\alpha$ & $\begin{array}{l}\text { Constitutive expression of K-RAS and } \\
\text { PML-RAR } \alpha\end{array}$ & $\begin{array}{l}\text { Rapid-onset and highly penetrant, lethal } \\
\text { APL-like disease }\end{array}$ & [170] \\
\hline & \multirow[t]{2}{*}{ N-RAS12D + BCL-2 } & $\begin{array}{l}\text { MMTVtTA /TBCL-2/NRASD12 } \\
\text { Expression of hBCL2 in a primitive } \\
\text { compartment by mouse mammary tumor } \\
\text { virus-long terminal repeat }\end{array}$ & $\begin{array}{l}\text { MDS development } \\
\text { Expanded leukemic stem cell } \\
\left(\mathrm{Lin}^{-} / \mathrm{Sca}-1^{+} / \mathrm{c}-\mathrm{Kit}{ }^{+}\right) \text {populations } \\
\text { Increased apoptosis } \\
\text { Malignant disease with a penetrance of } \\
\text { around } 80 \% \text { and a latency period of } 3 \text { to } 6 \\
\text { months }\end{array}$ & [175] \\
\hline & & $\begin{array}{l}\text { MRP8 [BCL-2/NRASD12] } \\
\text { Constitutive expression of BCL-2 under } \\
\text { human MRP8 promoter }\end{array}$ & $\begin{array}{l}\text { AML development } \\
\text { Expanded leukemic stem cell } \\
\left(\mathrm{Lin}^{-} / \mathrm{Sca}-1^{+} / \mathrm{c}-\mathrm{Kit}^{+}\right) \text {populations } \\
\text { No apoptotic cells } \\
\text { Malignant disease with a penetrance of } \\
\text { around } 80 \% \text { and a latency period of } 3 \text { to } 6 \\
\text { months }\end{array}$ & [175] \\
\hline & MLL-PTD + FLT3-ITD & $\begin{array}{l}\text { Expressing MLL-PTD and FLT3-ITD under } \\
\text { their respective endogenous promoters }\end{array}$ & $\begin{array}{l}\text { Latent AML with a short life span, extensive } \\
\text { extramedullary involvement and increased } \\
\text { aggressiveness } \\
\text { Normal chromosomal structures } \\
\text { Reduced MLL-WT expression } \\
\text { Loss of FLT3-WT and increased total FLT3 } \\
\text { expression } \\
\text { Increased HOXA9 transcript levels }\end{array}$ & [179] \\
\hline & NUP98-HOXD13 + FLT3-ITD & $\begin{array}{l}\text { Expressing FLT3-ITD and NHD13 (HOXD13) } \\
\text { under their respective endogenous } \\
\text { promoters }\end{array}$ & $\begin{array}{l}\text { Myeloid leukemia with minimal } \\
\text { differentiation } \\
\text { Overexpression of several } H O X \text { genes } \\
\text { Spontaneous loss of heterozygosity with a } \\
\text { high frequency, resulting in the loss of WT } \\
\text { FLT3 allele }\end{array}$ & [186] \\
\hline & NPM1c+ - FLT3 & $\begin{array}{l}\text { Crossing conditional Npm } 1^{f l o x-c A /+} \text { with } \\
\text { constitutive } F l t 3^{I T D /+} \text { mice }\end{array}$ & $\begin{array}{l}\text { AML development } \\
\text { Lethality by the age of } 31-68 \text { days } \\
\text { Modified blood cell counts } \\
\text { Immature blasts in BM } \\
\text { Myeloid cells infiltration into organs } \\
\text { Splenomegaly and hepatomegaly }\end{array}$ & [191] \\
\hline
\end{tabular}


Table 3. Cont

\begin{tabular}{|c|c|c|c|c|}
\hline \multicolumn{2}{|c|}{ Mouse Model } & \multirow[b]{2}{*}{$\begin{array}{l}\text { Allelic expression of oncogenic N-RAS }{ }^{\mathrm{G} 12 \mathrm{D}} \\
\text { and CBFB-MYH11 }\end{array}$} & \multirow[b]{2}{*}{\begin{tabular}{l}
\multicolumn{1}{c}{ Outcomes and Major Findings } \\
Leukemia development in a cell-autonomous \\
manner with a short median latency \\
High leukemia-initiating cell activity \\
Increased survival of pre-leukemic \\
short-term HSCs and myeloid progenitor \\
cells with blocked differentiation \\
Leukemic cells were sensitive to MEK/ERK \\
inhibitors
\end{tabular}} & \multirow{2}{*}{$\begin{array}{c}\text { References } \\
\text { [192] }\end{array}$} \\
\hline & N-RAS-G12D + CBFB-MYH11 & & & \\
\hline & NPM1c + N-RAS-G12D & $\begin{array}{l}\text { Conditional expression of } N P M 1 c+\text { and } \\
N-R A S-G 12 D\end{array}$ & $\begin{array}{l}\text { AML-like myeloid differentiation bias } \\
\text { Hematopoietic progenitors with high } \\
\text { penetrance and enhanced self-renewal } \\
\text { capacity } \\
\text { Frequent amplification of the mutant } \\
N-R A S-G 12 D \text { allele } \\
\text { Somatic mutations in AML driver genes } \\
\text { Overexpression of HOX genes }\end{array}$ & [193] \\
\hline & WT1-R394W + FLT3-ITD & $\begin{array}{l}\text { Crossing Flt } 3^{+/ T D} \text { mice with } W t 1^{+/ R 394 W} \\
\text { mice }\end{array}$ & $\begin{array}{l}\text { MDS/MPN development } \\
\text { Shortened survival } \\
\text { Myeloid expansion in the BM, } \\
\text { Anemia } \\
\text { Erythroid dysplasia }\end{array}$ & [197] \\
\hline \multirow[t]{4}{*}{ Xenograft/humanized models } & SCID mice & Autosomal recessive mutation & $\begin{array}{l}\text { Lack of B and T cells } \\
\text { Retained innate immunity and cytokines } \\
\text { Identification of leukemia initiating cells } \\
\text { (LIC) } \\
\text { Poor engraftment of human AML cells in the } \\
\text { BM }\end{array}$ & [200] \\
\hline & \multirow[t]{2}{*}{ NOD/SCID mice } & $\begin{array}{l}\text { NOD/SCID model: } \\
\text { Express additional mutations }\end{array}$ & $\begin{array}{l}\text { Impairment of NK activity } \\
\text { Reduced mature macrophages } \\
\text { Total lack of B and T cells } \\
\text { Fractionation of LIC into subpopulations }\end{array}$ & [211] \\
\hline & & $\begin{array}{l}\text { NSS model } \\
\text { (N/S-S/GM/3): variant of NOD/SCID mice } \\
\text { expressing SF, GM-CSF and IL-3 }\end{array}$ & Better host for a subset of AML & {$[222,223]$} \\
\hline & NSG mice & Deletion or truncation of the $\gamma$ chain of IL-2R & $\begin{array}{l}\text { Defective production of major interleukins } \\
\text { and IFN- } \gamma \\
\text { Impairment of dendritic cells } \\
\text { Complete abolishment of the NK cell activity } \\
\text { Higher engraftment capacity of human AML } \\
\text { cells than previous models }\end{array}$ & [224] \\
\hline
\end{tabular}


Table 4. Murine leukemia virus (MuLV) induced AML models: Major gene discoveries and their involvement in different French-American-British (FAB) AML subtypes.

\begin{tabular}{|c|c|c|c|c|c|}
\hline MuLV Virus & Mouse Strain & AML Subtype & FAB Classification & Major Gene Discoveries & References \\
\hline CasBrM-MuLV & NFS & Granulocytic & M1 or M2 & His-1 & {$[235,236]$} \\
\hline CasBrE MuLV & NIH Swiss & Myeloid & M1 or M2 & Fli-1 & [237-239] \\
\hline Endogenous ecotropic MuLV & AKXD-23 & Granulocytic & M1 or M2 & $E v i-1$ & {$[240,241]$} \\
\hline Friend-MuLV & C57BL/6 & Granulocytic & M1 or M2 & Cond1 1 & {$[237,242,243]$} \\
\hline Friend-MuLV & $\mathrm{DBA} / 2$ & Myeloblastic & M1 or M2 & $E v i-1, \mathcal{E} c-m y b$ & [244-246] \\
\hline M-MuLV & $\mathrm{BALB} / \mathrm{c}$ & Promonocytic & M5 & $c-m y b$ & {$[246,247]$} \\
\hline B ecotropic MuLV & BXH-2 & Myelomonocytic & M4 & $\begin{array}{c}\text { c-myb, HOXa7, HOXa9, Meis1, CBFa1, SOX4, } \\
\text { Hhex, Rarg, Sharp1, Ccnd3, Cdc25l, RASGRP, } \\
\text { Clabp, Hmgcr, Nf1, \& Il17r }\end{array}$ & [248-255] \\
\hline
\end{tabular}




\section{Drosophila Melanogaster}

AML1-ETO

The chromosomal translocation $\mathrm{t}(8: 21)(\mathrm{q} 22 ; \mathrm{q} 22)$ is frequent and common in AML. It represents up to $40 \%$ of AML subtype M2 of the FAB classification [256]. The fusion gene resulting in this translocation encodes for the chimeric protein AML1-ETO, which contains the N-terminus of AML1 (including its DNA binding domain) and most of the ETO protein [33,257], and inhibits the expression of AML1 target genes leading to leukemogenesis [258]. The detailed molecular mechanism governing this interference is poorly understood, which enticed the generation of several animal models to understand its mode of action. AML1-ETO alone is not sufficient to induce leukemia unless accompanied by secondary mutations $[130,131,259]$. The simplicity of genetics and ease of manipulation in Drosophila presents it as an attractive model to study this complex translocation. In addition, Drosophila hematopoiesis is comparable to that of mammals [260]. Two AML1-ETO models of genetically engineered Drosophila were generated. In the first model, AML1-ETO is a constitutive transcriptional repressor of AML1 target genes. In the second model, AML1-ETO dominantly interferes with AML1 activity by potentially competing for a common co-factor [261]. The transcription factor Lozenge (Lz) that is similar to human AML1 protein is necessary for the development of crystal cells, one of the major Drosophila blood cells, during hematopoiesis [262]. Using these models and by comparison with loss-of-function phenotypes of Lz, AML-1-ETO was shown to act as a constitutive transcriptional repressor [261]. Osman et al. reported that AML1-ETO inhibits the differentiation of crystal cell lineage, and induces an increase in the number of circulating LZ+ progenitors. Moreover, large scale RNA interference screen for suppressors of AML1-ETO in vivo showed that calpainB is required for AML1-ETO-induced leukemia in Drosophila. Surprisingly, calpainB inhibition in Kasumi-1 cells (AML patient cell line carrying $\mathrm{t}(8 ; 21)$ translocation) leads to AML1-ETO degradation and impairs their clonogenic potential [263]. Another study identified pontin/RUVBL1as a suppressor of AML1-ETO. Indeed, PONTIN knock-down inhibits the proliferation of $\mathrm{t}(8 ; 21)$ positive cells, and that PONTIN is essential for Kasumi- 1 clonogenic potential and cell cycle progression [264]. Thus, AML1-ETO can be recapitulated in Drosophila blood for investigating its mechanism and identifying potential targeted therapeutics for this AML subtype.

Despite advances in our understanding of many molecular mechanisms, in vitro research falls short in determining overall effect of treatment modalities or drug discovery. AML is an intricate disease where culture consisting of a single cell line system, can never recapitulate the complexity of the disease. In the difficulty of obtaining primate models of AML, small rodents, zebrafish, and Drosophila with well characterized genetic background and relative ease of manipulation, are the backbone of current work where leukemic cells are interfaced with the host immunity, metabolic environment and importance of the niche ation. Not one model is sufficient to address all posed questions. However, collectively, these models have expanded our knowledge and understanding of several pathways and important players in AML pathogenesis.

Author Contributions: All authors listed have made a substantial, direct and intellectual contribution to the work, and approved it for publication. H.S., B.J., R.H., M.H. writing-original draft preparation, N.D., A.B. writing-review and editing, M.E.S. and H.E.H. supervision, review and editing.

Funding: This research received no external funding.

Conflicts of Interest: The authors declare no conflict of interest.

\section{References}

1. Lowenberg, B.; Downing, J.R.; Burnett, A. Acute myeloid leukemia. N. Engl. J. Med. 1999, 341, $1051-1062$. [CrossRef] [PubMed]

2. Yamamoto, J.F.; Goodman, M.T. Patterns of leukemia incidence in the United States by subtype and demographic characteristics, 1997-2002. Cancer Causes Control 2008, 19, 379-390. [CrossRef] [PubMed] 
3. Maynadie, M.; Girodon, F.; Manivet-Janoray, I.; Mounier, M.; Mugneret, F.; Bailly, F.; Favre, B.; Caillot, D.; Petrella, T.; Flesch, M.; et al. Twenty-five years of epidemiological recording on myeloid malignancies: Data from the specialized registry of hematologic malignancies of Cote d'Or (Burgundy, France). Haematologica 2011, 96, 55-61. [CrossRef] [PubMed]

4. Dohner, H.; Weisdorf, D.J.; Bloomfield, C.D. Acute Myeloid Leukemia. N. Engl. J. Med. 2015, 373, $1136-1152$. [CrossRef] [PubMed]

5. Deschler, B.; Lübbert, M. Acute myeloid leukemia: Epidemiology and etiology. Cancer 2006, 107, $2099-2107$. [CrossRef] [PubMed]

6. Lowenberg, B.; Suciu, S.; Archimbaud, E.; Haak, H.; Stryckmans, P.; de Cataldo, R.; Dekker, A.W.; Berneman, Z.N.; Thyss, A.; van der Lelie, J.; et al. Mitoxantrone versus daunorubicin in induction-consolidation chemotherapy-The value of low-dose cytarabine for maintenance of remission, and an assessment of prognostic factors in acute myeloid leukemia in the elderly: Final report. European Organization for the Research and Treatment of Cancer and the Dutch-Belgian Hemato-Oncology Cooperative Hovon Group. J. Clin. Oncol. 1998, 16, 872-881. [PubMed]

7. Bennett, J.M.; Catovsky, D.; Daniel, M.-T.; Flandrin, G.; Galton, D.A.G.; Gralnick, H.R.; Sultan, C. Proposals for the Classification of the Acute Leukaemias French-American-British (FAB) Co-operative Group. Br. J. Haematol. 1976, 33, 451-458. [CrossRef] [PubMed]

8. Vardiman, J.W.; Harris, N.L.; Brunning, R.D. The World Health Organization (WHO) classification of the myeloid neoplasms. Blood 2002, 100, 2292-2302. [CrossRef]

9. Vardiman, J.W.; Thiele, J.; Arber, D.A.; Brunning, R.D.; Borowitz, M.J.; Porwit, A.; Harris, N.L.; Le Beau, M.M.; Hellström-Lindberg, E.; Tefferi, A.; et al. The 2008 revision of the World Health Organization (WHO) classification of myeloid neoplasms and acute leukemia: Rationale and important changes. Blood 2009, 114, 937-951. [CrossRef]

10. Arber, D.A.; Orazi, A.; Hasserjian, R.; Thiele, J.; Borowitz, M.J.; Le Beau, M.M.; Bloomfield, C.D.; Cazzola, M.; Vardiman, J.W. The 2016 revision to the World Health Organization classification of myeloid neoplasms and acute leukemia. Blood 2016, 127, 2391-2405. [CrossRef]

11. Dohner, H.; Estey, E.H.; Amadori, S.; Appelbaum, F.R.; Buchner, T.; Burnett, A.K.; Dombret, H.; Fenaux, P.; Grimwade, D.; Larson, R.A.; et al. Diagnosis and management of acute myeloid leukemia in adults: Recommendations from an international expert panel, on behalf of the European LeukemiaNet. Blood 2010, 115, 453-474. [CrossRef] [PubMed]

12. Dohner, H.; Estey, E.; Grimwade, D.; Amadori, S.; Appelbaum, F.R.; Buchner, T.; Dombret, H.; Ebert, B.L.; Fenaux, P.; Larson, R.A.; et al. Diagnosis and management of AML in adults: 2017 ELN recommendations from an international expert panel. Blood 2017, 129, 424-447. [CrossRef] [PubMed]

13. Weinstein, J.N.; Collisson, E.A.; Mills, G.B.; Shaw, K.M.; Ozenberger, B.A.; Ellrott, K.; Shmulevich, I.; Sander, C.; Stuart, J.M. The Cancer Genome Atlas Pan-Cancer Analysis Project. Nat. Genet. 2013, 45, 1113-1120. [CrossRef] [PubMed]

14. Ley, T.J.; Miller, C.; Ding, L.; Raphael, B.J.; Mungall, A.J.; Robertson, A.; Hoadley, K.; Triche, T.J., Jr.; Laird, P.W.; Baty, J.D.; et al. Genomic and epigenomic landscapes of adult de novo acute myeloid leukemia. N. Engl. J. Med. 2013, 368, 2059-2074. [PubMed]

15. Howe, K.; Clark, M.D.; Torroja, C.F.; Torrance, J.; Berthelot, C.; Muffato, M.; Collins, J.E.; Humphray, S.; McLaren, K.; Matthews, L.; et al. The zebrafish reference genome sequence and its relationship to the human genome. Nature 2013, 496, 498-503. [CrossRef]

16. Stuart, G.W.; McMurray, J.V.; Westerfield, M. Replication, integration and stable germ-line transmission of foreign sequences injected into early zebrafish embryos. Development 1988, 103, 403-412. [PubMed]

17. Hwang, W.Y.; Fu, Y.; Reyon, D.; Maeder, M.L.; Tsai, S.Q.; Sander, J.D.; Peterson, R.T.; Yeh, J.R.; Joung, J.K. Efficient genome editing in zebrafish using a CRISPR-Cas system. Nat. Biotechnol. 2013, 31, 227-229. [CrossRef]

18. Rasighaemi, P.; Basheer, F.; Liongue, C.; Ward, A.C. Zebrafish as a model for leukemia and other hematopoietic disorders. J. Hematol. Oncol. 2015, 8, 35. [CrossRef]

19. Macrae, C.A.; Peterson, R.T. Zebrafish as tools for drug discovery. Nat. Rev. Drug Discov. 2015, 14, 721-731. [CrossRef] 
20. Pruvot, B.; Jacquel, A.; Droin, N.; Auberger, P.; Bouscary, D.; Tamburini, J.; Muller, M.; Fontenay, M.; Chluba, J.; Solary, E. Leukemic cell xenograft in zebrafish embryo for investigating drug efficacy. Haematologica 2011, 96, 612-616. [CrossRef]

21. Dick, A.; Hild, M.; Bauer, H.; Imai, Y.; Maifeld, H.; Schier, A.F.; Talbot, W.S.; Bouwmeester, T.; Hammerschmidt, M. Essential role of Bmp7 (snailhouse) and its prodomain in dorsoventral patterning of the zebrafish embryo. Development 2000, 127, 343-354. [PubMed]

22. Schmid, B.; Fürthauer, M.; Connors, S.A.; Trout, J.; Thisse, B.; Thisse, C.; Mullins, M.C. Equivalent genetic roles for bmp7/snailhouse and bmp2b/swirl in dorsoventral pattern formation. Development 2000, 127, 957-967. [PubMed]

23. Kishimoto, Y.; Lee, K.H.; Zon, L.; Hammerschmidt, M.; Schulte-Merker, S. The molecular nature of zebrafish swirl: BMP2 function is essential during early dorsoventral patterning. Development 1997, 124, 4457-4466. [PubMed]

24. Paik, E.J.; Zon, L.I. Hematopoietic development in the zebrafish. Int. J. Dev. Boil. 2010, 54, 1127-1137. [CrossRef] [PubMed]

25. Carapeti, M.; Aguiar, R.C.; Goldman, J.M.; Cross, N.C. A novel fusion between MOZ and the nuclear receptor coactivator TIF2 in acute myeloid leukemia. Blood 1998, 91, 3127-3133.

26. Coulthard, S.; Chase, A.; Watmore, A.; Swirsky, D.M.; Orchard, K.; Vora, A.; Goldman, J.M. Two cases of $\operatorname{inv}(8)($ 11q13) in AML with erythrophagocytosis: A new cytogenetic variant. Br. J. Haematol. 1998, 100, 561-563. [CrossRef] [PubMed]

27. Aguiar, R.C.; Chase, A.; Coulthard, S.; Macdonald, D.H.; Carapeti, M.; Reiter, A.; Sohal, J.; Lennard, A.; Goldman, J.M.; Cross, N.C. Abnormalities of chromosome band 8p11 in leukemia: Two clinical syndromes can be distinguished on the basis of MOZ involvement. Blood 1997, 90, 3130-3135.

28. Liang, J.; Prouty, L.; Williams, B.J.; Dayton, M.A.; Blanchard, K.L. Acute mixed lineage leukemia with an $\operatorname{inv}(8)($ p11q13) resulting in fusion of the genes for MOZ and TIF2. Blood 1998, 92, 2118-2122.

29. Zhuravleva, J.; Paggetti, J.; Martin, L.; Hammann, A.; Solary, E.; Bastie, J.-N.; Delva, L. MOZ/TIF2-induced acute myeloid leukaemia in transgenic fish. Br. J. Haematol. 2008, 143, 378-382. [CrossRef]

30. Hsu, K.; Traver, D.; Kutok, J.L.; Hagen, A.; Liu, T.-X.; Paw, B.H.; Rhodes, J.; Berman, J.N.; Zon, L.I.; Kanki, J.P.; et al. The pu.1 promoter drives myeloid gene expression in zebrafish. Blood 2004, 104, 1291-1297. [CrossRef]

31. Voso, M.T.; Burn, T.C.; Wulf, G.; Lim, B.; Leone, G.; Tenen, D.G. Inhibition of hematopoiesis by competitive binding of transcription factor PU. Proc. Natl. Acad. Sci. USA 1994, 91, 7932-7936. [CrossRef] [PubMed]

32. Rowley, J.D. Identificaton of a translocation with quinacrine fluorescence in a patient with acute leukemia. Ann. Genet. 1973, 16, 109-112. [PubMed]

33. Erickson, P.; Gao, J.; Chang, K.S.; Look, T.; Whisenant, E.; Raimondi, S.; Lasher, R.; Trujillo, J.; Rowley, J.; Drabkin, H. Identification of breakpoints in $\mathrm{t}(8 ; 21)$ acute myelogenous leukemia and isolation of a fusion transcript, AML1/ETO, with similarity to Drosophila segmentation gene, runt. Blood 1992, 80, 1825-1831. [PubMed]

34. Miyoshi, H.; Shimizu, K.; Kozu, T.; Maseki, N.; Kaneko, Y.; Ohki, M. t(8;21) breakpoints on chromosome 21 in acute myeloid leukemia are clustered within a limited region of a single gene, AML1. Proc. Natl. Acad. Sci. USA 1991, 88, 10431-10434. [CrossRef] [PubMed]

35. Nisson, P.E.; Watkins, P.C.; Sacchi, N. Transcriptionally active chimeric gene derived from the fusion of the AML1 gene and a novel gene on chromosome 8 in t(8;21) leukemic cells. Cancer Genet. Cytogenet. 1992, 63, 81-88. [CrossRef]

36. Yeh, J.R.; Munson, K.M.; Chao, Y.L.; Peterson, Q.P.; Macrae, C.A.; Peterson, R.T. AML1-ETO reprograms hematopoietic cell fate by downregulating scl expression. Development 2008, 135, 401-410. [CrossRef] [PubMed]

37. Yeh, J.-R.J.; Munson, K.M.; Elagib, K.E.; Goldfarb, A.N.; Sweetser, D.A.; Peterson, R.T. Discovering chemical modifiers of oncogene-regulated hematopoietic differentiation. Nat. Methods 2009, 5, 236-243. [CrossRef] [PubMed]

38. Hirvonen, H.; Hukkanen, V.; Salmi, T.T.; Mäkelä, T.P.; Pelliniemi, T.T.; Knuutila, S.; Alitalo, R. Expression of L-myc and N-myc proto-oncogenes in human leukemias and leukemia cell lines. Blood 1991, 78, 3012-3020. [PubMed] 
39. Hirvonen, H.; Hukkanen, V.; Salmi, T.T.; Pelliniemi, T.T.; Alitalo, R. L-myc and N-myc in hematopoietic malignancies. Leuk Lymphoma 1993, 11, 197-205. [CrossRef] [PubMed]

40. Ross, M.E.; Mahfouz, R.; Onciu, M.; Liu, H.-C.; Zhou, X.; Song, G.; Shurtleff, S.A.; Pounds, S.; Cheng, C.; Ma, J.; et al. Gene expression profiling of pediatric acute myelogenous leukemia. Blood 2004, 104, 3679-3687. [CrossRef] [PubMed]

41. Shen, L.J.; Chen, F.Y.; Zhang, Y.; Cao, L.F.; Kuang, Y.; Zhong, M.; Wang, T.; Zhong, H. MYCN transgenic zebrafish model with the characterization of acute myeloid leukemia and altered hematopoiesis. PLoS ONE 2013, 8, e59070. [CrossRef] [PubMed]

42. Mackarehtschian, K.; Hardin, J.D.; Moore, K.A.; Boast, S.; Goff, S.P.; Lemischka, I.R. Targeted disruption of the flk2/flt3 gene leads to deficiencies in primitive hematopoietic progenitors. Immunity 1995, 3, 147-161. [CrossRef]

43. Carow, C.E.; Levenstein, M.; Kaufmann, S.H.; Chen, J.; Amin, S.; Rockwell, P.; Witte, L.; Borowitz, M.J.; Civin, C.I.; Small, D. Expression of the hematopoietic growth factor receptor FLT3 (STK-1/Flk2) in human leukemias. Blood 1996, 87, 1089-1096. [PubMed]

44. Rosnet, O.; Bühring, H.J.; Marchetto, S.; Rappold, I.; Lavagna, C.; Sainty, D.; Arnoulet, C.; Chabannon, C.; Kanz, L.; Hannum, C.; et al. Human FLT3/FLK2 receptor tyrosine kinase is expressed at the surface of normal and malignant hematopoietic cells. Leukemia 1996, 10, 238-248. [PubMed]

45. Kiyoi, H.; Ohno, R.; Ueda, R.; Saito, H.; Naoe, T. Mechanism of constitutive activation of FLT3 with internal tandem duplication in the juxtamembrane domain. Oncogene 2002, 21, 2555-2563. [CrossRef] [PubMed]

46. Horiike, S.; Yokota, S.; Nakao, M.; Iwai, T.; Sasai, Y.; Kaneko, H.; Taniwaki, M.; Kashima, K.; Fujii, H.; Abe, T.; et al. Tandem duplications of the FLT3 receptor gene are associated with leukemic transformation of myelodysplasia. Leukemia 1997, 11, 1442-1446. [CrossRef] [PubMed]

47. Kiyoi, H.; Naoe, T.; Nakano, Y.; Yokota, S.; Minami, S.; Miyawaki, S.; Asou, N.; Kuriyama, K.; Jinnai, I.; Shimazaki, C.; et al. Prognostic implication of FLT3 and N-RAS gene mutations in acute myeloid leukemia. Blood 1999, 93, 3074-3080.

48. Yu, Y.; Maggi, L.B.; Brady, S.N.; Apicelli, A.J.; Dai, M.-S.; Lu, H.; Weber, J.D. Nucleophosmin Is Essential for Ribosomal Protein L5 Nuclear Export. Mol. Cell. Boil. 2006, 26, 3798-3809. [CrossRef]

49. Savkur, R. Preferential cleavage in pre-ribosomal RNA byprotein B23 endoribonuclease. Nucleic Acids Res. 1998, 26, 4508-4515. [CrossRef]

50. Falini, B.; Mecucci, C.; Tiacci, E.; Alcalay, M.; Rosati, R.; Pasqualucci, L.; La Starza, R.; Diverio, D.; Colombo, E.; Santucci, A.; et al. Cytoplasmic nucleophosmin in acute myelogenous leukemia with a normal karyotype. $N$. Engl. J. Med. 2005, 352, 254-266. [CrossRef]

51. He, B.-L.; Shi, X.; Man, C.H.; Ma, A.C.H.; Ekker, S.C.; Chow, H.C.H.; So, C.W.E.; Choi, W.W.L.; Zhang, W.; Zhang, Y.; et al. Functions of flt3 in zebrafish hematopoiesis and its relevance to human acute myeloid leukemia. Blood 2014, 123, 2518-2529. [CrossRef] [PubMed]

52. Bolli, N.; Payne, E.M.; Grabher, C.; Lee, J.S.; Johnston, A.B.; Falini, B.; Kanki, J.P.; Look, A.T. Expression of the cytoplasmic NPM1 mutant (NPMc+) causes the expansion of hematopoietic cells in zebrafish. Blood 2010, 115, 3329-3340. [CrossRef] [PubMed]

53. Lu, J.-W.; Hou, H.-A.; Hsieh, M.-S.; Tien, H.-F.; Lin, L.-I. Overexpression of FLT3-ITD driven by spi-1 results in expanded myelopoiesis with leukemic phenotype in zebrafish. Leukemia 2016, 30, 2098-2101. [CrossRef] [PubMed]

54. Cheng, J.C.; Kinjo, K.; Judelson, D.R.; Chang, J.; Wu, W.S.; Schmid, I.; Shankar, D.B.; Kasahara, N.; Stripecke, R.; Bhatia, R.; et al. CREB is a critical regulator of normal hematopoiesis and leukemogenesis. Blood 2008, 111, 1182-1192. [CrossRef] [PubMed]

55. Kinjo, K.; Sandoval, S.; Sakamoto, K.M.; Shankar, D.B. The Role of CREB as a Proto-oncogene in Hematopoiesis. Cell Cycle 2005, 4, 1134-1135. [CrossRef] [PubMed]

56. Crans, H.N.; Sakamoto, K.M. Transcription factors and translocations in lymphoid and myeloid leukemia. Leukemia 2001, 15, 313-331. [CrossRef] [PubMed]

57. Tregnago, C.; Manara, E.; Zampini, M.; Bisio, V.; Borga, C.; Bresolin, S.; Aveic, S.; Germano, G.; Basso, G.; Pigazzi, M. CREB engages C/EBPdelta to initiate leukemogenesis. Leukemia 2016, 30, 1887-1896. [CrossRef]

58. Gubbay, J.; Collignon, J.; Koopman, P.; Capel, B.; Economou, A.; Münsterberg, A.; Vivian, N.; Goodfellow, P.; Lovell-Badge, R. A gene mapping to the sex-determining region of the mouse $\mathrm{Y}$ chromosome is a member of a novel family of embryonically expressed genes. Nature 1990, 346, 245-250. [CrossRef] 
59. Lu, J.W.; Hsieh, M.S.; Hou, H.A.; Chen, C.Y.; Tien, H.F.; Lin, L.I. Overexpression of SOX4 correlates with poor prognosis of acute myeloid leukemia and is leukemogenic in zebrafish. Blood Cancer J. 2017, 7, e593. [CrossRef]

60. Zhang, H.; Alberich-Jorda, M.; Amabile, G.; Yang, H.; Staber, P.B.; Di Ruscio, A.; Welner, R.S.; Ebralidze, A.; Zhang, J.; Levantini, E.; et al. Sox4 is a key oncogenic target in C/EBPalpha mutant acute myeloid leukemia. Cancer Cell 2013, 24, 575-588. [CrossRef]

61. Fung, T.K.; Leung, A.Y.; So, C.W. Sox4you: A new player in C/EBPalpha leukemia. Cancer Cell 2013, 24, 557-559. [CrossRef] [PubMed]

62. Paschka, P.; Schlenk, R.F.; Gaidzik, V.I.; Habdank, M.; Krönke, J.; Bullinger, L.; Späth, D.; Kayser, S.; Zucknick, M.; Götze, K.; et al. IDH1 and IDH2 Mutations Are Frequent Genetic Alterations in Acute Myeloid Leukemia and Confer Adverse Prognosis in Cytogenetically Normal Acute Myeloid Leukemia with NPM1 Mutation Without FLT3 Internal Tandem Duplication. J. Clin. Oncol. 2010, 28, 3636-3643. [CrossRef] [PubMed]

63. Shi, X.; He, B.-L.; Ma, A.C.H.; Guo, Y.; Chi, Y.; Man, C.H.; Zhang, W.; Zhang, Y.; Wen, Z.; Cheng, T.; et al. Functions of idh1 and its mutation in the regulation of developmental hematopoiesis in zebrafish. Blood 2015, 125, 2974-2984. [CrossRef] [PubMed]

64. Guryev, V.; Koudijs, M.J.; Berezikov, E.; Johnson, S.L.; Plasterk, R.H.; van Eeden, F.J.; Cuppen, E. Genetic variation in the zebrafish. Genome Res. 2006, 16, 491-497. [CrossRef] [PubMed]

65. Svejda, J.; Kossey, P.; Hlavayova, E.; Svec, F. Histological picture of the transplantable rat leukaemia induced by x-irradiation and methylcholanthrene. Neoplasma 1958, 5, 123-131. [PubMed]

66. Huggins, C.B.; Sugiyama, T. Induction of leukemia in rat by pulse doses of 7,12-dimethylbenz(a)anthracene. Proc. Natl. Acad. Sci. USA 1966, 55, 74-81. [CrossRef] [PubMed]

67. Huggins, C.B.; Grand, L.; Ueda, N. Specific induction of erythroleukemia and myelogenous leukemia in Sprague-Dawley rats. Proc. Natl. Acad. Sci. USA 1982, 79, 5411-5414. [CrossRef] [PubMed]

68. Somfai, S.; Szentirmay, Z.; Gál, F. Transplantable Myeloid Rat Leukaemia Induced by 7,12-Dimethylbenz(a)anthracene. Acta Haematol. 1973, 49, 281-290.

69. Bekkum, D.W.; van Hagenbeek, A. Relevance of the BN leukemia as a model for human acute myeloid leukemia. Blood Cells Mol. Dis. 1977, 3, 565-579.

70. Van Bekkum, D.W.; Van Oosterom, P.; Dicke, K.A. In vitro colony formation of transplantable rat leukemias in comparison with human acute myeloid leukemia. Cancer Res. 1976, 36, 941-946.

71. Hagenbeek, A.; van Bekkum, D.W. Comparitive evaluation of the L5222 and the BNML rat leukaemia models and their relavance to human acute leukaemia. Leuk. Res. 1977, 1, 75-256. [CrossRef]

72. Nooter, K.; Sonneveld, P.; Deurloo, J.; Oostrum, R.; Schultz, F.; Martens, A.; Hagenbeek, A. Repeated daunomycin administration in rats. Cancer Chemother. Pharmacol. 1984, 12, 187-189. [CrossRef] [PubMed]

73. Sonneveld, P.; Van Bekkum, D.W. Different distribution of adriamycin in normal and leukaemic rats. Br. J. Cancer 1981, 43, 464-470. [CrossRef] [PubMed]

74. Colly, L.P.; Van Bekkum, D.W.; Hagenbeek, A. Enhanced tumor load reduction after chemotherapy induced recruitment and synchronization in a slowly growing rat leukemia model (BNML) for human acute myelocytic leukemia. Leuk. Res. 1984, 8, 953-963. [CrossRef]

75. Aglietta, M.; Sonneveld, P. The relevance of cell kinetics for optimal scheduling of 1-beta-D-arabinofuranosyl cytosine and methotrexate in a slow growing acute myeloid leukemia (BNML). Cancer Chemother. Pharmacol. 1978, 1, 219-223. [CrossRef] [PubMed]

76. Hagenbeek, A.; Martens, A.C. AMSA: In vivo log cell kill for leukemic clonogenic cells versus toxicity for normal hemopoietic stem cells in a rat model for human acute myelocytic leukemia (BNML). Eur. J. Cancer Clin. Oncol. 1986, 22, 1255-1258. [CrossRef]

77. Ermens, A.A.; Kroes, A.C.; Lindemans, J.; Abels, J. 5-Fluorouracil treatment of rat leukemia and a reappraisal of its application in human leukemia. Anticancer Res. 1986, 6, 797-800. [PubMed]

78. Kroes, A.C.M.; Lindemans, J.; Schoester, M.; Abels, J. Enhanced therapeutic effect of methotrexate in experimental rat leukemia after inactivation of cobalamin (vitamin B12) by nitrous oxide. Cancer Chemother. Pharmacol. 1986, 17, 114-120. [CrossRef] [PubMed]

79. Sonneveld, P.; Holcenberg, J.; Van Bekkum, D. Effect of succinylated Acinetobacter glutaminase-asparaginase treatment on an acute myeloid leukemia in the rat (BNML). Eur. J. Cancer (1965) 1979, 15, 1061-1063. [CrossRef] 
80. Arkesteijn, G.J.A.; Martens, A.C.M.; Jonker, R.R.; Hagemeijer, A.; Hagenbeek, A. Bivariate flow karyotyping of acute myelocytic leukemia in the BNML rat model. Cytometry 1987, 8, 618-624. [CrossRef]

81. Martens, A.C.M.; Hagenbeek, A. Detection of minimal disease in acute leukemia using flow cytometry: Studies in a rat model for human acute leukemia. Cytometry 1985, 6, 342-347. [CrossRef] [PubMed]

82. Martens, A.C.M.; Van Bekkum, D.W.; Hagenbeek, A. Minimal residual disease in leukemia: Studies in an animal model for acute myelocytic leukemia (bnml). Stem Cells 1990, 8, 27-38. [CrossRef] [PubMed]

83. Law, L.W.; Taormina, V.; Boyle, P.J. Response of acute lymphocytic leukemias to the purine antagonist 6-mercaptopurine. Ann. N. Y. Acad. Sci. 1954, 60, 244-250. [CrossRef] [PubMed]

84. Skipper, H.E.; Perry, S. Kinetics of normal and leukemic leukocyte populations and relevance to chemotherapy. Cancer Res. 1970, 30, 1883-1897. [PubMed]

85. Casazza, A.M.; Pratesi, G.; Giuliani, F.; Di Marco, A. Antileukemic Activity of 4-Demethoxydaunorubicin in Mice. Tumori J. 1980, 66, 549-564. [CrossRef]

86. Law, L.W.; Dunn, T.B.; Boyle, P.J.; Miller, J.H. Observations on the Effect of a Folic-Acid Antagonist on Transplantable Lymphoid Leukemias in Mice. J. Natl. Cancer Inst. 1949, 10, 179-192.

87. Kline, I.; Venditti, J.M.; Mead, J.A.; Tyrer, D.D.; Goldin, A. The antileukemic effectiveness of 5-fluorouracil and methotrexate in the combination chemotherapy of advanced leukemia L1210 in mice. Cancer Res. 1966, 26, 848-852. [PubMed]

88. Kline, I.; Venditti, J.M.; Tyrer, D.D.; Mantel, N.; Goldin, A. Chemotherapy of leukemia L1210 in mice with 1-beta-D-arabinofuranosylcytosine hydrochloride. II. Effectiveness against intracerebrally and subcutaneously inoculated leukemic cells. Cancer Res. 1966, 26, 1930-1937. [PubMed]

89. Jensen, P.B.; Roed, H.; Skovsgaard, T.; Friche, E.; Spang-Thomsen, M. Antitumor activity of the two epipodophyllotoxin derivatives VP-16 and VM-26 in preclinical systems: A comparison of in vitro and in vivo drug evaluation. Cancer Chemother. Pharmacol. 1990, 27, 194-198. [CrossRef] [PubMed]

90. Skipper, H.E.; Schabel, F.M.; Wilcox, W.S. Experimental evaluation of potential anticancer agents. XXI. Scheduling of arabinosylcytosine to take advantage of its S-phase specificity against leukemia cells. Cancer Chemother. Rep. 1967, 51, 125-165. [PubMed]

91. Kawasaki, Y.; Hirabayashi, Y.; Kaneko, T.; Kanno, J.; Kodama, Y.; Matsushima, Y.; Ogawa, Y.; Saitoh, M.; Sekita, K.; Uchida, O.; et al. Benzene-Induced Hematopoietic Neoplasms Including Myeloid Leukemia in Trp53-Deficient C57BL/6 and C3H/He Mice. Toxicol. Sci. 2009, 110, 293-306. [CrossRef] [PubMed]

92. Preston, D.L.; Kusumi, S.; Tomonaga, M.; Izumi, S.; Ron, E.; Kuramoto, A.; Kamada, N.; Dohy, H.; Matsuo, T.; Matsui, T.; et al. Cancer incidence in atomic bomb survivors. Part III. Leukemia, lymphoma and multiple myeloma, 1950-1987. Radiat. Res. 1994, 137 (Suppl. 2), S68-S97. [CrossRef] [PubMed]

93. Weiss, H.A.; Boice, J.D.; Muirhead, C.R.; Little, M.P.; Darby, S.C.; Day, N.E. Risks of Leukemia in Japanese Atomic Bomb Survivors, in Women Treated for Cervical Cancer, and in Patients Treated for Ankylosing Spondylitis. Radiat. Res. 1999, 152, 280.

94. Tomonaga, M. Leukaemia in Nagasaki atomic bomb survivors from 1945 through 1959. Bull. World Health Organ. 1962, 26, 619-631. [PubMed]

95. Finch, S.C. Radiation-induced leukemia: Lessons from history. Best Pract. Res. Clin. Haematol. 2007, 20, 109-118. [CrossRef] [PubMed]

96. Silver, A.; Moody, J.; Dunford, R.; Clark, D.; Ganz, S.; Bulman, R.; Bouffler, S.; Finnon, P.; Meijne, E.; Huiskamp, R.; et al. Molecular mapping of chromosome 2 deletions in murine radiation-induced AML localizes a putative tumor suppressor gene to a $1.0 \mathrm{cM}$ region homologous to human chromosome segment 11p11-12. Genes Chromosome Cancer 1999, 24, 95-104. [CrossRef]

97. Furth, J.; Seibold, H.R.; Rathbone, R.R. Experimental studies on lymphomatosis. Am. J. Cancer 1933, 19, 521-604.

98. Ullrich, R.L.; Preston, R.J. Myeloid leukemia in male RFM mice following irradiation with fission spectrum neutrons or gamma rays. Radiat. Res. 1987, 109, 165-170. [CrossRef]

99. Wolman, S.R.; McMorrow, L.E.; Cohen, M.W. Animal model of human disease: Myelogenous leukemia in the RF mouse. Am. J. Pathol. 1982, 107, 280-284.

100. Finnon, R.; Brown, N.; Moody, J.; Badie, C.; Olme, C.-H.; Huiskamp, R.; Meijne, E.; Sutmuller, M.; Rosemann, M.; Bouffler, S.D. Flt3-ITD mutations in a mouse model of radiation-induced acute myeloid leukaemia. Leukemia 2012, 26, 1445-1446. [CrossRef] 
101. Small, D. FLT3 mutations: Biology and treatment. Hematol. Am. Soc. Hematol. Educ. Program 2006, $178-184$. [CrossRef] [PubMed]

102. Dunn, T.B. Normal and Pathologic Anatomy of the Reticular Tissue in Laboratory Mice, With a Classification and Discussion of Neoplasms. J. Natl. Cancer Inst. 1954, 14, 1281-1433. [PubMed]

103. Pedersen-Bjergaard, J.; Philip, P.; Pedersen, N.T.; Hou-Jensen, K.; Svejgaard, A.; Jensen, G.; Nissen, N.I. Acute nonlymphocytic leukemia, preleukemia, and acute myeloproliferative syndrome secondary to treatment of other malignant diseases. II. Bone marrow cytology, cytogenetics, results of HLA typing, response to antileukemic chemotherapy, and survival in a total series of 55 patients. Cancer 1984, 54, 452-462. [PubMed]

104. Haran-Ghera, N.; Krautghamer, R.; Lapidot, T.; Peled, A.; Dominguez, M.G.; Stanley, E.R. Increased circulating colony-stimulating factor-1 (CSF-1) in SJL/J mice with radiation-induced acute myeloid leukemia (AML) is associated with autocrine regulation of AML cells by CSF-1. Blood 1997, 89, 2537-2545. [PubMed]

105. Chia, R.; Achilli, F.; Festing, M.F.W.; Fisher, E.M.C. The origins and uses of mouse outbred stocks. Nat. Genet. 2005, 37, 1181-1186. [CrossRef] [PubMed]

106. Ban, N.; Kai, M.; Kusama, T. Chromosome Aberrations in Bone Marrow Cells of C3H/He Mice at an Early Stage after Whole-Body Irradiation. J. Radiat. Res. 1997, 38, 219-231. [CrossRef] [PubMed]

107. Rithidech, K.; Dunn, J.J.; Bond, V.P.; Gordon, C.R.; Cronkite, E.P. Characterization of genetic instability in radiation- and benzene-induced murine acute leukemia. Mutat. Res. Mol. Mech. Mutagen. 1999, 428, 33-39. [CrossRef]

108. Cleary, H. Allelic loss on chromosome 4 (Lyr2/TLSR5) is associated with myeloid, B-lympho-myeloid, and lymphoid (B and T) mouse radiation-induced leukemias. Blood 2001, 98, 1549-1554. [CrossRef]

109. Giotopoulos, G.; McCormick, C.; Cole, C.; Zanker, A.; Jawad, M.; Brown, R.; Plumb, M. DNA methylation during mouse hemopoietic differentiation and radiation-induced leukemia. Exp. Hematol. 2006, 34, 1462-1470. [CrossRef]

110. Siegler, R.; Rich, M.A. Pathogenesis of Virus-Induced Myeloid Leukemia in Mice. J. Natl. Cancer Inst. 1967, 38, 31-50.

111. McGarry, M.P.; Steeves, R.A.; Eckner, R.J.; Mirand, E.A.; Trudel, P.J. Isolation of a myelogenous leukemia-inducing virus from mice infected with the friend virus complex. Int. J. Cancer 1974, 13, 867-878. [CrossRef] [PubMed]

112. Rein, A. Murine Leukemia Viruses: Objects and Organisms. Adv. Virol. 2011, 2011, 1-14. [CrossRef] [PubMed]

113. Gross, L. Development and serial cellfree passage of a highly potent strain of mouse leukemia virus. Proc. Soc. Exp. Biol. Med. 1957, 94, 767-771. [CrossRef] [PubMed]

114. Linemeyer, D.L.; Menke, J.G.; Ruscetti, S.K.; Evans, L.H.; Scolnick, E.M. Envelope gene sequences which encode the gp52 protein of spleen focus-forming virus are required for the induction of erythroid cell proliferation. J. Virol. 1982, 43, 223-233. [PubMed]

115. Ruscetti, S.; Wolff, L. Malignant transformation of erythroid cells in vivo by introduction of a nonreplicating retrovirus vector. Science 1985, 228, 1549-1552.

116. Perkins, A.S. The Pathology of Murine Myelogenous Leukemias. Curr. Top. Microbiol. Immunol. 1989, 149, 3-21.

117. Largaespada, D.A. Genetic heterogeneity in acute myeloid leukemia: Maximizing information flow from MuLV mutagenesis studies. Leukemia 2000, 14, 1174-1184. [CrossRef]

118. Dupuy, A.J. Transposon-based screens for cancer gene discovery in mouse models. Semin. Cancer Biol. 2010, 20, 261-268. [CrossRef]

119. Largaespada, D.A. Transposon-mediated mutagenesis of somatic cells in the mouse for cancer gene identification. Methods 2009, 49, 282-286. [CrossRef]

120. Collier, L.S.; Adams, D.J.; Hackett, C.S.; Bendzick, L.E.; Akagi, K.; Davies, M.N.; Diers, M.D.; Rodriguez, F.J.; Bender, A.M.; Tieu, C.; et al. Whole-body Sleeping Beauty mutagenesis can cause penetrant leukemia/lymphoma and rare high-grade glioma without associated embryonic lethality. Cancer Res. 2009, 69, 8429-8437. [CrossRef]

121. Vassiliou, G.S.; Cooper, J.L.; Rad, R.; Li, J.; Rice, S.; Uren, A.; Rad, L.; Ellis, P.; Andrews, R.; Banerjee, R.; et al. Mutant nucleophosmin and cooperating pathways drive leukemia initiation and progression in mice. Nat. Genet. 2011, 43, 470-475. [PubMed] 
122. Kakizuka, A.; Miller, W.H.; Umesono, K.; Warrell, R.P.; Frankel, S.R.; Murty, V.V.; Dmitrovsky, E.; Evans, R.M. Chromosomal translocation $\mathrm{t}(15 ; 17)$ in human acute promyelocytic leukemia fuses RAR alpha with a novel putative transcription factor, PML. Cell 1991, 66, 663-674. [CrossRef]

123. De Thé, H.; Lavau, C.; Marchio, A.; Chomienne, C.; Degos, L.; Dejean, A. The PML-RAR alpha fusion mRNA generated by the $\mathrm{t}(15 ; 17)$ translocation in acute promyelocytic leukemia encodes a functionally altered RAR. Cell 1991, 66, 675-684. [CrossRef]

124. Early, E.; Moore, M.A.; Kakizuka, A.; Nason-Burchenal, K.; Martin, P.; Evans, R.M.; Dmitrovsky, E. Transgenic expression of PML/RARalpha impairs myelopoiesis. Proc. Natl. Acad. Sci. USA 1996, 93, 7900-7904. [CrossRef] [PubMed]

125. Grisolano, J.L.; Wesselschmidt, R.L.; Pelicci, P.G.; Ley, T.J. Altered myeloid development and acute leukemia in transgenic mice expressing PML-RAR alpha under control of cathepsin G regulatory sequences. Blood 1997, 89, 376-387. [PubMed]

126. Brown, D.; Kogan, S.; Lagasse, E.; Weissman, I.; Alcalay, M.; Pelicci, P.G.; Atwater, S.; Bishop, J.M. A PMLRARalpha transgene initiates murine acute promyelocytic leukemia. Proc. Natl. Acad. Sci. USA 1997, 94, 2551-2556. [CrossRef] [PubMed]

127. Wang, Q.; Stacy, T.; Binder, M.; Marin-Padilla, M.; Sharpe, A.H.; Speck, N.A. Disruption of the Cbfa2 gene causes necrosis and hemorrhaging in the central nervous system and blocks definitive hematopoiesis. Proc. Natl. Acad. Sci. USA 1996, 93, 3444-3449. [CrossRef]

128. Okuda, T.; Van Deursen, J.; Hiebert, S.W.; Grosveld, G.; Downing, J.R. AML1, the Target of Multiple Chromosomal Translocations in Human Leukemia, Is Essential for Normal Fetal Liver Hematopoiesis. Cell 1996, 84, 321-330. [CrossRef]

129. Okuda, T.; Cai, Z.; Yang, S.; Lenny, N.; Lyu, C.J.; Van Deursen, J.M.; Harada, H.; Downing, J.R. Expression of a knocked-in AML1-ETO leukemia gene inhibits the establishment of normal definitive hematopoiesis and directly generates dysplastic hematopoietic progenitors. Blood 1998, 91, 3134-3143.

130. Rhoades, K.L.; Hetherington, C.J.; Harakawa, N.; Yergeau, D.A.; Zhou, L.; Liu, L.Q.; Little, M.T.; Tenen, D.G.; Zhang, D.E. Analysis of the role of AML1-ETO in leukemogenesis, using an inducible transgenic mouse model. Blood 2000, 96, 2108-2115.

131. Higuchi, M.; O’Brien, D.; Kumaravelu, P.; Lenny, N.; Yeoh, E.-J.; Downing, J.R. Expression of a conditional AML1-ETO oncogene bypasses embryonic lethality and establishes a murine model of human $\mathrm{t}(8 ; 21)$ acute myeloid leukemia. Cancer Cell 2002, 1, 63-74. [CrossRef]

132. Yuan, Y.; Zhou, L.; Miyamoto, T.; Iwasaki, H.; Harakawa, N.; Hetherington, C.J.; Burel, S.A.; Lagasse, E.; Weissman, I.L.; Akashi, K.; et al. AML1-ETO expression is directly involved in the development of acute myeloid leukemia in the presence of additional mutations. Proc. Natl. Acad. Sci. USA 2001, 98, 10398-10403. [CrossRef] [PubMed]

133. Nick, H.J.; Kim, H.G.; Chang, C.W.; Harris, K.W.; Reddy, V.; Klug, C.A. Distinct classes of c-Kit-activating mutations differ in their ability to promote RUNX1-ETO-associated acute myeloid leukemia. Blood 2012, 119, 1522-1531. [CrossRef]

134. Schessl, C.; Rawat, V.P.; Cusan, M.; Deshpande, A.; Kohl, T.M.; Rosten, P.M.; Spiekermann, K.; Humphries, R.K.; Schnittger, S.; Kern, W.; et al. The AML1-ETO fusion gene and the FLT3 length mutation collaborate in inducing acute leukemia in mice. J. Clin. Investig. 2005, 115, 2159-2168. [CrossRef] [PubMed]

135. Wang, S.; Wang, Q.; Crute, B.E.; Melnikova, I.N.; Keller, S.R.; Speck, N.A. Cloning and characterization of subunits of the T-cell receptor and murine leukemia virus enhancer core-binding factor. Mol. Cell. Boil. 1993, 13, 3324-3339. [CrossRef] [PubMed]

136. Schoch, C.; Kern, W.; Schnittger, S.; Büchner, T.; Hiddemann, W.; Haferlach, T. The influence of age on prognosis of de novo acute myeloid leukemia differs according to cytogenetic subgroups. Haematologica 2004, 89, 1082-1090. [PubMed]

137. Liu, P.; Tarlé, S.; Hajra, A.; Claxton, D.; Marlton, P.; Freedman, M.; Siciliano, M.; Collins, F. Fusion between transcription factor CBF beta/PEBP2 beta and a myosin heavy chain in acute myeloid leukemia. Science 1993, 261, 1041-1044. [CrossRef] [PubMed]

138. Castilla, L.H.; Garrett, L.; Adya, N.; Orlic, D.; Dutra, A.; Anderson, S.; Owens, J.; Eckhaus, M.; Bodine, D.; Liu, P.P. The fusion gene Cbfb-MYH11 blocks myeloid differentiation and predisposes mice to acute myelomonocytic leukaemia. Nat. Genet. 1999, 23, 144-146. [CrossRef] [PubMed] 
139. Castilla, L.H.; Perrat, P.; Martinez, N.J.; Landrette, S.F.; Keys, R.; Oikemus, S.; Flanegan, J.; Heilman, S.; Garrett, L.; Dutra, A.; et al. Identification of genes that synergize with Cbfb-MYH11 in the pathogenesis of acute myeloid leukemia. Proc. Natl. Acad. Sci. USA 2004, 101, 4924-4929. [CrossRef]

140. Kuo, Y.H.; Landrette, S.F.; Heilman, S.A.; Perrat, P.N.; Garrett, L.; Liu, P.P.; Le Beau, M.M.; Kogan, S.C.; Castilla, L.H. Cbf beta-SMMHC induces distinct abnormal myeloid progenitors able to develop acute myeloid leukemia. Cancer Cell 2006, 9, 57-68. [CrossRef]

141. Verhaak, R.G.W. Mutations in nucleophosmin (NPM1) in acute myeloid leukemia (AML): Association with other gene abnormalities and previously established gene expression signatures and their favorable prognostic significance. Blood 2005, 106, 3747-3754. [CrossRef] [PubMed]

142. Cheng, K.; Sportoletti, P.; Ito, K.; Clohessy, J.G.; Teruya-Feldstein, J.; Kutok, J.L.; Pandolfi, P.P. The cytoplasmic NPM mutant induces myeloproliferation in a transgenic mouse model. Blood 2010, 115, 3341-3345. [CrossRef] [PubMed]

143. Chou, S.H.; Ko, B.S.; Chiou, J.S.; Hsu, Y.C.; Tsai, M.H.; Chiu, Y.C.; Yu, I.S.; Lin, S.W.; Hou, H.A.; Kuo, Y.Y.; et al. A knock-in Npm1 mutation in mice results in myeloproliferation and implies a perturbation in hematopoietic microenvironment. PLoS ONE 2012, 7, e49769. [CrossRef] [PubMed]

144. Mallardo, M.; Caronno, A.; Pruneri, G.; Raviele, P.R.; Viale, A.; Pelicci, P.G.; Colombo, E. NPMc+ and FLT3_ITD mutations cooperate in inducing acute leukaemia in a novel mouse model. Leukemia 2013, 27, 2248-2251. [CrossRef] [PubMed]

145. Gilliland, D.G.; Griffin, J.D. The roles of FLT3 in hematopoiesis and leukemia. Blood 2002, 100, $1532-1542$. [CrossRef] [PubMed]

146. Lee, B.H.; Williams, I.R.; Anastasiadou, E.; Boulton, C.L.; Joseph, S.W.; Amaral, S.M.; Curley, D.P.; Duclos, N.; Huntly, B.J.P.; Fabbro, D.; et al. FLT3 internal tandem duplication mutations induce myeloproliferative or lymphoid disease in a transgenic mouse model. Oncogene 2005, 24, 7882-7892. [CrossRef] [PubMed]

147. Li, L.; Bailey, E.; Greenblatt, S.; Huso, D.; Small, D. Loss of the wild-type allele contributes to myeloid expansion and disease aggressiveness in FLT3/ITD knockin mice. Blood 2011, 118, 4935-4945. [CrossRef] [PubMed]

148. Lee, B.H.; Tothova, Z.; Levine, R.L.; Anderson, K.; Buza-Vidas, N.; Cullen, D.E.; McDowell, E.P.; Adelsperger, J.; Fröhling, S.; Huntly, B.J.; et al. FLT3 mutations confer enhanced proliferation and survival properties to multipotent progenitors in a murine model of chronic myelomonocytic leukemia. Cancer Cell 2007, 12, 367-380. [CrossRef]

149. Kharazi, S.; Mead, A.J.; Mansour, A.; Hultquist, A.; Böiers, C.; Luc, S.; Buza-Vidas, N.; Ma, Z.; Ferry, H.; Atkinson, D.; et al. Impact of gene dosage, loss of wild-type allele, and FLT3 ligand on Flt3-ITD-induced myeloproliferation. Blood 2011, 118, 3613-3621. [CrossRef]

150. Iida, S.; Seto, M.; Yamamoto, K.; Komatsu, H.; Tojo, A.; Asano, S.; Kamada, N.; Ariyoshi, Y.; Takahashi, T.; Ueda, R. MLLT3 gene on 9p22 involved in $\mathrm{t}(9 ; 11)$ leukemia encodes a serine/proline rich protein homologous to MLLT1 on 19p13. Oncogene 1993, 8, 3085-3092.

151. Nakamura, T.; Alder, H.; Gu, Y.; Prasad, R.; Canaani, O.; Kamada, N.; Gale, R.P.; Lange, B.; Crist, W.M.; Nowell, P.C.; et al. Genes on chromosomes 4, 9, and 19 involved in 11q23 abnormalities in acute leukemia share sequence homology and/or common motifs. Proc. Natl. Acad. Sci. USA 1993, 90, 4631-4635. [CrossRef] [PubMed]

152. Corral, J.; Lavenir, I.; Impey, H.; Warren, A.J.; Forster, A.; Larson, T.A.; Bell, S.; McKenzie, A.N.; King, G.; Rabbitts, T.H. An Mll-AF9 Fusion Gene Made by Homologous Recombination Causes Acute Leukemia in Chimeric Mice: A Method to Create Fusion Oncogenes. Cell 1996, 85, 853-861. [CrossRef]

153. Collins, E.C.; Pannell, R.; Simpson, E.M.; Forster, A.; Rabbitts, T.H. Inter-chromosomal recombination of Mll and Af9 genes mediated by cre-loxP in mouse development. EMBO Rep. 2000, 1, 127-132. [CrossRef] [PubMed]

154. Stavropoulou, V.; Kaspar, S.; Brault, L.; Sanders, M.A.; Juge, S.; Morettini, S.; Tzankov, A.; Iacovino, M.; Lau, I.-J.; Milne, T.A.; et al. MLL-AF9 Expression in Hematopoietic Stem Cells Drives a Highly Invasive AML Expressing EMT-Related Genes Linked to Poor Outcome. Cancer Cell 2016, 30, 43-58. [CrossRef]

155. Johnson, J.J.; Chen, W.; Hudson, W.; Yao, Q.; Taylor, M.; Rabbitts, T.H.; Kersey, J.H. Prenatal and postnatal myeloid cells demonstrate stepwise progression in the pathogenesis of MLL fusion gene leukemia. Blood 2003, 101, 3229-3235. [CrossRef] [PubMed] 
156. Ayton, P.M.; Cleary, M.L. Transformation of myeloid progenitors by MLL oncoproteins is dependent on Hoxa7 and Hoxa9. Genome Res. 2003, 17, 2298-2307. [CrossRef] [PubMed]

157. Meyer, C.; Hofmann, J.; Burmeister, T.; Gröger, D.; Park, T.S.; Emerenciano, M.; Pombo-De-Oliveira, M.D.S.; Renneville, A.; Villarese, P.; MacIntyre, E.; et al. The MLL recombinome of acute leukemias in 2013. Leukemia 2013, 27, 2165-2176. [CrossRef] [PubMed]

158. Chen, W.; Li, Q.; Hudson, W.A.; Kumar, A.; Kirchhof, N.; Kersey, J.H. A murine Mll-AF4 knock-in model results in lymphoid and myeloid deregulation and hematologic malignancy. Blood 2006, 108, 669-677. [CrossRef] [PubMed]

159. Metzler, M.; Förster, A.; Pannell, R.; Arends, M.J.; Daser, A.; Lobato, M.N.; Rabbitts, T.H. A conditional model of MLL-AF4 B-cell tumourigenesis using invertor technology. Oncogene 2006, 25, 3093-3103. [CrossRef]

160. Barrett, N.A.; Malouf, C.; Kapeni, C.; Bacon, W.A.; Giotopoulos, G.; Jacobsen, S.E.W.; Huntly, B.J.; Ottersbach, K. Mll-AF4 Confers Enhanced Self-Renewal and Lymphoid Potential during a Restricted Window in Development. Cell Rep. 2016, 16, 1039-1054. [CrossRef]

161. Krivtsov, A.V.; Feng, Z.; Lemieux, M.E.; Faber, J.; Vempati, S.; Sinha, A.U.; Xia, X.; Jesneck, J.; Bracken, A.P.; Silverman, L.B.; et al. H3K79 methylation profiles define murine and human MLL-AF4 leukemias. Cancer Cell 2008, 14, 355-368. [CrossRef] [PubMed]

162. Lavau, C.; Szilvassy, S.J.; Slany, R.; Cleary, M.L. Immortalization and leukemic transformation of a myelomonocytic precursor by retrovirally transduced HRX-ENL. EMBO J. 1997, 16, 4226-4237. [CrossRef] [PubMed]

163. Zeisig, B.B.; García-Cuéllar, M.P.; Winkler, T.H.; Slany, R.K. The Oncoprotein MLL-ENL disturbs hematopoietic lineage determination and transforms a biphenotypic lymphoid/myeloid cell. Oncogene 2003, 22, 1629-1637. [CrossRef] [PubMed]

164. Zeisig, B.B.; Milne, T.; García-Cuéllar, M.-P.; Schreiner, S.; Martin, M.-E.; Fuchs, U.; Borkhardt, A.; Chanda, S.K.; Walker, J.; Soden, R.; et al. Hoxa9 and Meis1 are key targets for MLL-ENL-mediated cellular immortalization. Mol. Cell. Boil. 2004, 24, 617-628. [CrossRef] [PubMed]

165. Kennedy, J.A.; Hope, K.J.; Dick, J.E.; Barabé, F. Modeling the Initiation and Progression of Human Acute Leukemia in Mice. Science 2007, 316, 600-604.

166. Ugale, A.; Säwén, P.; Dudenhöffer-Pfeifer, M.; Wahlestedt, M.; Norddahl, G.L.; Bryder, D. MLL-ENL-mediated leukemia initiation at the interface of lymphoid commitment. Oncogene 2017, 36, 3207-3212. [CrossRef] [PubMed]

167. Sasaki, M.; Knobbe, C.B.; Munger, J.C.; Lind, E.F.; Brenner, D.; Brüstle, A.; Harris, I.S.; Holmes, R.; Wakeham, A.; Haight, J.; et al. IDH1(R132H) mutation increases murine haematopoietic progenitors and alters epigenetics. Nature 2012, 488, 656-659. [CrossRef]

168. Callens, C.; Chevret, S.; Cayuela, J.M.; Cassinat, B.; Raffoux, E.; de Botton, S.; Thomas, X.; Guerci, A.; Fegueux, N.; Pigneux, A.; et al. Prognostic implication of FLT3 and Ras gene mutations in patients with acute promyelocytic leukemia (APL): A retrospective study from the European APL Group. Leukemia 2005, 19, 1153-1160. [CrossRef]

169. Bowen, D.T.; Frew, M.E.; Hills, R.; Gale, R.E.; Wheatley, K.; Groves, M.J.; Langabeer, S.E.; Kottaridis, P.D.; Moorman, A.V.; Burnett, A.K.; et al. RAS mutation in acute myeloid leukemia is associated with distinct cytogenetic subgroups but does not influence outcome in patients younger than 60 years. Blood 2005, 106, 2113-2119. [CrossRef]

170. Chan, I.T.; Kutok, J.L.; Williams, I.R.; Cohen, S.; Moore, S.; Shigematsu, H.; Ley, T.J.; Akashi, K.; Le Beau, M.M.; Gilliland, D.G. Oncogenic K-ras cooperates with PML-RAR alpha to induce an acute promyelocytic leukemia-like disease. Blood 2006, 108, 1708-1715. [CrossRef]

171. Taylor, C.; McGlynn, H.; Carter, G.; Baker, A.H.; Warren, N.; Ridge, S.A.; Owen, G.; Thompson, E.; Thompson, P.W.; Jacobs, A. RAS and FMS mutations following cytotoxic therapy for childhood acute lymphoblastic leukaemia. Leukemia 1995, 9, 466-470. [PubMed]

172. Padua, R.A.; Guinn, B.-A.; Al-Sabah, A.I.; Smith, M.; Taylor, C.; Pettersson, T.; Ridge, S.; Carter, G.; White, D.; Oscier, D.; et al. RAS, FMS and p53 mutations and poor clinical outcome in myelodysplasias: A 10-year follow-up. Leukemia 1998, 12, 887-892. [CrossRef] [PubMed]

173. Karakas, T.; Maurer, U.; Weidmann, E.; Miething, C.C.; Hoelzer, D.; Bergmann, L. High expression of bcl-2 mRNA as a determinant of poor prognosis in acute myeloid leukemia. Ann. Oncol. 1998, 9, 159-165. [CrossRef] [PubMed] 
174. Benito, A.; Grillot, D.; Nuñez, G.; Fernández-Luna, J.L. Regulation and function of Bcl-2 during differentiation-induced cell death in HL-60 promyelocytic cells. Am. J. Pathol. 1995, 146, 481-490. [PubMed]

175. Omidvar, N.; Kogan, S.; Beurlet, S.; Le Pogam, C.; Janin, A.; West, R.; Noguera, M.-E.; Reboul, M.; Soulié, A.; Leboeuf, C.; et al. BCL-2 and Mutant NRAS Interact Physically and Functionally in a Mouse Model of Progressive Myelodysplasia. Cancer Res. 2007, 67, 11657-11667. [CrossRef] [PubMed]

176. Steudel, C.; Wermke, M.; Schaich, M.; Schakel, U.; Illmer, T.; Ehninger, G.; Thiede, C. Comparative analysis of MLL partial tandem duplication and FLT3 internal tandem duplication mutations in 956 adult patients with acute myeloid leukemia. Genes Chromosomes Cancer 2003, 37, 237-251. [CrossRef] [PubMed]

177. Shih, L.Y.; Liang, D.C.; Fu, J.F.; Wu, J.H.; Wang, P.N.; Lin, T.L.; Dunn, P.; Kuo, M.C.; Tang, T.C.; Lin, T.H.; et al. Characterization of fusion partner genes in 114 patients with de novo acute myeloid leukemia and MLL rearrangement. Leukemia 2006, 20, 218-223. [CrossRef]

178. Whitman, S.P.; Ruppert, A.S.; Marcucci, G.; Mrózek, K.; Paschka, P.; Langer, C.; Baldus, C.D.; Wen, J.; Vukosavljevic, T.; Powell, B.L.; et al. Long-term disease-free survivors with cytogenetically normal acute myeloid leukemia and MLL partial tandem duplication: A Cancer and Leukemia Group B study. Blood 2007, 109, 5164-5167. [CrossRef]

179. Zorko, N.A.; Bernot, K.M.; Whitman, S.P.; Siebenaler, R.F.; Ahmed, E.H.; Marcucci, G.G.; Yanes, D.A.; McConnell, K.K.; Mao, C.; Kalu, C.; et al. Mll partial tandem duplication and Flt3 internal tandem duplication in a double knock-in mouse recapitulates features of counterpart human acute myeloid leukemias. Blood 2012, 120, 1130-1136. [CrossRef]

180. Whitman, S.P.; Archer, K.J.; Feng, L.; Baldus, C.; Becknell, B.; Carlson, B.D.; Carroll, A.J.; Mrózek, K.; Vardiman, J.W.; George, S.L.; et al. Absence of the wild-type allele predicts poor prognosis in adult de novo acute myeloid leukemia with normal cytogenetics and the internal tandem duplication of FLT3: A cancer and leukemia group B study. Cancer Res. 2001, 61, 7233-7239.

181. Whitman, S.P.; Liu, S.; Vukosavljevic, T.; Rush, L.J.; Yu, L.; Liu, C.; Klisovic, M.I.; Maharry, K.; Guimond, M.; Strout, M.P.; et al. The MLL partial tandem duplication: Evidence for recessive gain-of-function in acute myeloid leukemia identifies a novel patient subgroup for molecular-targeted therapy. Blood 2005, 106, 345-352. [CrossRef] [PubMed]

182. Döhner, K.; Tobis, K.; Ulrich, R.; Fröhling, S.; Benner, A.; Schlenk, R.F. Prognostic Significance of Partial Tandem Duplications of the MLL Gene in Adult Patients 16 to 60 Years Old With Acute Myeloid Leukemia and Normal Cytogenetics: A Study of the Acute Myeloid Leukemia Study Group Ulm. J. Clin. Oncol. 2002, 20, 3254-3261. [CrossRef] [PubMed]

183. Raza-Egilmez, S.Z.; Jani-Sait, S.N.; Grossi, M.; Higgins, M.J.; Shows, T.B.; Aplan, P.D. NUP98-HOXD13 gene fusion in therapy-related acute myelogenous leukemia. Cancer Res. 1998, 58, 4269-4273. [PubMed]

184. Slape, C.; Lin, Y.W.; Hartung, H.; Zhang, Z.; Wolff, L.; Aplan, P.D. NUP98-HOX translocations lead to myelodysplastic syndrome in mice and men. Journal of the National Cancer Institute. Monographs 2008, 64-68. [CrossRef] [PubMed]

185. Palmqvist, L.; Argiropoulos, B.; Pineault, N.; Abramovich, C.; Sly, L.M.; Krystal, G.; Wan, A.; Humphries, R.K. The Flt3 receptor tyrosine kinase collaborates with NUP98-HOX fusions in acute myeloid leukemia. Blood 2006, 108, 1030-1036. [CrossRef] [PubMed]

186. Greenblatt, S.; Li, L.; Slape, C.; Nguyen, B.; Novak, R.; Duffield, A.; Huso, D.; Desiderio, S.; Borowitz, M.J.; Aplan, P.; et al. Knock-in of a FLT3/ITD mutation cooperates with a NUP98-HOXD13 fusion to generate acute myeloid leukemia in a mouse model. Blood 2012, 119, 2883-2894. [CrossRef]

187. Giampaolo, A.; Felli, N.; Diverio, D.; Morsilli, O.; Samoggia, P.; Breccia, M.; Coco, F.L.; Peschle, C.; Testa, U. Expression pattern of HOXB6 homeobox gene in myelomonocytic differentiation and acute myeloid leukemia. Leukemia 2002, 16, 1293-1301. [CrossRef]

188. Amsellem, S.; Pflumio, F.; Bardinet, D.; Izac, B.; Charneau, P.; Roméo, P.-H.; Dubart-Kupperschmitt, A.; Fichelson, S. Ex vivo expansion of human hematopoietic stem cells by direct delivery of the HOXB4 homeoprotein. Nat. Med. 2003, 9, 1423-1427. [CrossRef]

189. Soulier, J.; Clappier, E.; Cayuela, J.-M.; Regnault, A.; García-Peydró, M.; Dombret, H.; Baruchel, A.; Toribio, M.-L.; Sigaux, F. HOXA genes are included in genetic and biologic networks defining human acute T-cell leukemia (T-ALL). Blood 2005, 106, 274-286. [CrossRef] 
190. Papaemmanuil, E.; Gerstung, M.; Bullinger, L.; Gaidzik, V.I.; Paschka, P.; Roberts, N.D.; Potter, N.E.; Heuser, M.; Thol, F.; Bolli, N.; et al. Genomic Classification and Prognosis in Acute Myeloid Leukemia. N. Engl. J. Med. 2016, 374, 2209-2221. [CrossRef]

191. Mupo, A.; Celani, L.; Dovey, O.; Cooper, J.L.; Grove, C.; Rad, R.; Sportoletti, P.; Falini, B.; Bradley, A.; Vassiliou, G.S. A powerful molecular synergy between mutant Nucleophosmin and Flt3-ITD drives acute myeloid leukemia in mice. Leukemia 2013, 27, 1917-1920. [CrossRef] [PubMed]

192. Xue, L.; Pulikkan, J.A.; Valk, P.J.; Castilla, L.H. NrasG12D oncoprotein inhibits apoptosis of preleukemic cells expressing Cbfbeta-SMMHC via activation of MEK/ERK axis. Blood 2014, 124, 426-436. [CrossRef] [PubMed]

193. Dovey, O.M.; Cooper, J.L.; Mupo, A.; Grove, C.S.; Lynn, C.; Conte, N.; Andrews, R.M.; Pacharne, S.; Tzelepis, K.; Vijayabaskar, M.S.; et al. Molecular synergy underlies the co-occurrence patterns and phenotype of NPM1-mutant acute myeloid leukemia. Blood 2017, 130, 1911-1922. [CrossRef] [PubMed]

194. Ellisen, L.W.; Carlesso, N.; Cheng, T.; Scadden, D.T.; Haber, D.A. The Wilms tumor suppressor WT1 directs stage-specific quiescence and differentiation of human hematopoietic progenitor cells. EMBO J. 2001, 20, 1897-1909. [CrossRef] [PubMed]

195. Summers, K.; Stevens, J.; Kakkas, I.; Smith, M.; Smith, L.L.; MacDougall, F.; Cavenagh, J.; Bonnet, D.; Young, B.D.; Lister, T.A.; et al. Wilms' tumour 1 mutations are associated with FLT3-ITD and failure of standard induction chemotherapy in patients with normal karyotype AML. Leukemia 2007, 21, 550-551. [CrossRef] [PubMed]

196. Hou, H.-A.; Huang, T.-C.; Lin, L.-I.; Liu, C.-Y.; Chen, C.-Y.; Chou, W.-C.; Tang, J.-L.; Tseng, M.-H.; Huang, C.-F.; Chiang, Y.-C.; et al. WT1 mutation in 470 adult patients with acute myeloid leukemia: Stability during disease evolution and implication of its incorporation into a survival scoring system. Blood 2010, 115, 5222-5231. [CrossRef]

197. Annesley, C.E.; Rabik, C.; Duffield, A.S.; Rau, R.E.; Magoon, D.; Li, L.; Huff, V.; Small, D.; Loeb, D.M.; Brown, P. Knock-in of the Wt1 R394W mutation causes MDS and cooperates with Flt3/ITD to drive aggressive myeloid neoplasms in mice. Oncotarget 2018, 9, 35313-35326. [CrossRef]

198. Nara, N.; Miyamoto, T. Direct and serial transplantation of human acute myeloid leukaemia into nude mice. Br. J. Cancer 1982, 45, 778-782. [CrossRef]

199. Caretto, P.; Forni, M.; d’Orazi, G.; Scarpa, S.; Feraiorni, P.; Jemma, C.; Modesti, A.; Ferrarini, M.; Roncella, S.; Foa, R.; et al. Xenotransplantation in immunosuppressed nude mice of human solid tumors and acute leukemias directly from patients or in vitro cell lines. Res. Clin. Lab. 1989, 19, 231-243.

200. Bosma, G.C.; Custer, R.P.; Bosma, M.J. A severe combined immunodeficiency mutation in the mouse. Nature 1983, 301, 527-530. [CrossRef]

201. De Lord, C.; Clutterbuck, R.; Titley, J.; Ormerod, M.; Gordon-Smith, T.; Millar, J.; Powles, R. Growth of primary human acute leukemia in severe combined immunodeficient mice. Exp. Hematol. 1991, 19, 991-993.

202. Lapidot, T.; Sirard, C.; Vormoor, J.; Murdoch, B.; Hoang, T.; Caceres-Cortes, J.; Minden, M.; Paterson, B.; Caligiuri, M.A.; Dick, J.E. A cell initiating human acute myeloid leukaemia after transplantation into SCID mice. Nature 1994, 367, 645-648. [CrossRef] [PubMed]

203. Yan, Y.; Salomon, O.; McGuirk, J.; Dennig, D.; Fernandez, J.; Jagiello, C.; Nguyen, H.; Collins, N.; Steinherz, P.; O'Reilly, R.J. Growth pattern and clinical correlation of subcutaneously inoculated human primary acute leukemias in severe combined immunodeficiency mice. Blood 1996, 88, 3137-3146.

204. Lapidot, T.; Pflumio, F.; Doedens, M.; Murdoch, B.; Williams, D.; Dick, J. Cytokine stimulation of multilineage hematopoiesis from immature human cells engrafted in SCID mice. Science 1992, 255, 1137-1141. [CrossRef] [PubMed]

205. Goan, S.R.; Fichtner, I.; Just, U.; Karawajew, L.; Schultze, W.; Krause, K.P.; Von Harsdorf, S.; Von Schilling, C.; Herrmann, F. The severe combined immunodeficient-human peripheral blood stem cell (SCID-huPBSC) mouse: A xenotransplant model for huPBSC-initiated hematopoiesis. Blood 1995, 86, 89-100. [PubMed]

206. Cashman, J.D.; Lapidot, T.; Wang, J.C.; Doedens, M.; Shultz, L.D.; Lansdorp, P.; Dick, J.E.; Eaves, C.J. Kinetic evidence of the regeneration of multilineage hematopoiesis from primitive cells in normal human bone marrow transplanted into immunodeficient mice. Blood 1997, 89, 4307-4316.

207. Nonoyama, S.; Smith, F.O.; Bernstein, I.D.; Ochs, H.D. Strain-dependent leakiness of mice with severe combined immune deficiency. J. Immunol. 1993, 150, 3817-3824.

208. Carroll, A.M.; Hardy, R.R.; Bosma, M.J. Occurrence of mature B (IgM+, B220+) and T (CD3+) lymphocytes in scid mice. J. Immunol. 1989, 143, 1087-1093. 
209. Kudo, T.; Saijyo, S.; Saeki, H.; Sato, N.; Tachibana, T.; Habu, S. Production of a Human Monoclonal Antibody to a Synthetic Peptide by Active In Vivo Immunization Using a SCID Mouse Grafted with Human Lymphocytes. Tohoku J. Exp. Med. 1993, 171, 327-338. [CrossRef]

210. Shpitz, B.; Chambers, C.A.; Singhal, A.B.; Hozumi, N.; Fernandes, B.J.; Roifman, C.M.; Weiner, L.M.; Roder, J.C.; Gallinger, S. High level functional engraftment of severe combined immunodeficient mice with human peripheral blood lymphocytes following pretreatment with radiation and anti-asialo GM. J. Immunol. Methods 1994, 169, 1-15. [CrossRef]

211. Shultz, L.D.; Schweitzer, P.A.; Christianson, S.W.; Gott, B.; Schweitzer, I.B.; Tennent, B.; McKenna, S.; Mobraaten, L.; Rajan, T.V.; Greiner, D.L. Multiple defects in innate and adaptive immunologic function in NOD/LtSz-scid mice. J. Immunol. 1995, 154, 180-191. [PubMed]

212. Bonnet, D.; Dick, J.E. Human acute myeloid leukemia is organized as a hierarchy that originates from a primitive hematopoietic cell. Nat. Med. 1997, 3, 730-737. [CrossRef] [PubMed]

213. Ailles, L.E.; Gerhard, B.; Kawagoe, H.; Hogge, D.E. Growth characteristics of acute myelogenous leukemia progenitors that initiate malignant hematopoiesis in nonobese diabetic/severe combined immunodeficient mice. Blood 1999, 94, 1761-1772. [PubMed]

214. Lumkul, R.; Gorin, N.-C.; Malehorn, M.T.; Hoehn, G.T.; Zheng, R.; Baldwin, B.; Small, D.; Gore, S.; Smith, D.; Meltzer, P.S.; et al. Human AML cells in NOD/SCID mice: Engraftment potential and gene expression. Leukemia 2002, 16, 1818-1826. [CrossRef] [PubMed]

215. Marx, J. Cancer research. Mutant stem cells may seed cancer. Science 2003, 301, 1308-1310. [CrossRef] [PubMed]

216. Ye, P.; Zhao, L.; McGirr, C.; Gonda, T.J. MYB down-regulation enhances sensitivity of U937 myeloid leukemia cells to the histone deacetylase inhibitor LBH589 in vitro and in vivo. Cancer Lett. 2014, 343, 98-106. [CrossRef] [PubMed]

217. Blair, A.; Hogge, D.E.; Sutherland, H.J. Most acute myeloid leukemia progenitor cells with long-term proliferative ability in vitro and in vivo have the phenotype CD34(+)/CD71(-)/HLA-DR. Blood 1998, 92, 4325-4335.

218. Blair, A.; Hogge, D.E.; Ailles, L.E.; Lansdorp, P.M.; Sutherland, H.J. Lack of expression of Thy-1 (CD90) on acute myeloid leukemia cells with long-term proliferative ability in vitro and in vivo. Blood 1997, 89, 3104-3112.

219. Blair, A.; Sutherland, H.J. Primitive acute myeloid leukemia cells with long-term proliferative ability in vitro and in vivo lack surface expression of c-kit (CD117). Exp. Hematol. 2000, 28, 660-671. [CrossRef]

220. Ahmed, F.; Ings, S.J.; Pizzey, A.R.; Blundell, M.P.; Thrasher, A.J.; Ye, H.T.; Fahey, A.; Linch, D.C.; Yong, K.L. Impaired bone marrow homing of cytokine-activated CD34+ cells in the NOD/SCID model. Blood 2004, 103, 2079-2087. [CrossRef]

221. Bonnet, D.; Bhatia, M.; Wang, J.C.Y.; Kapp, U.; Dick, J.E. Cytokine treatment or accessory cells are required to initiate engraftment of purified primitive human hematopoietic cells transplanted at limiting doses into NOD/SCID mice. Bone Marrow Transplant. 1999, 23, 203-209. [CrossRef] [PubMed]

222. Feuring-Buske, M.; Gerhard, B.; Cashman, J.; Humphries, R.K.; Eaves, C.J.; Hogge, D.E.; Humphries, R. Improved engraftment of human acute myeloid leukemia progenitor cells in beta 2-microglobulin-deficient NOD/SCID mice and in NOD/SCID mice transgenic for human growth factors. Leukemia 2003, 17, 760-763. [CrossRef] [PubMed]

223. Wunderlich, M.; Chou, F.-S.; Link, K.I.; Mizukawa, B.; Perry, R.L.; Carroll, M.; Mulloy, J.C. AML xenograft efficiency is significantly improved in NOD/SCID-IL2RG mice constitutively expressing human SCF, GM-CSF and IL-3. Leukemia 2010, 24, 1785-1788. [CrossRef] [PubMed]

224. Koller, B.H.; Smithies, O. Inactivating the beta 2-microglobulin locus in mouse embryonic stem cells by homologous recombination. Proc. Natl. Acad. Sci. USA 1989, 86, 8932-8935. [CrossRef] [PubMed]

225. Ito, M.; Hiramatsu, H.; Kobayashi, K.; Suzue, K.; Kawahata, M.; Hioki, K.; Ueyama, Y.; Koyanagi, Y.; Sugamura, K.; Tsuji, K.; et al. NOD/SCID/gamma(c)(null) mouse: An excellent recipient mouse model for engraftment of human cells. Blood 2002, 100, 3175-3182. [CrossRef] [PubMed]

226. Ishikawa, F.; Yasukawa, M.; Lyons, B.; Yoshida, S.; Miyamoto, T.; Yoshimoto, G.; Watanabe, T.; Akashi, K.; Shultz, L.D.; Harada, M. Development of functional human blood and immune systems in NOD/SCID/IL2 receptor \{gamma\} chain(null) mice. Blood 2005, 106, 1565-1573. [CrossRef] [PubMed] 
227. Agliano, A.; Martin-Padura, I.; Mancuso, P.; Marighetti, P.; Rabascio, C.; Pruneri, G.; Shultz, L.D.; Bertolini, F. Human acute leukemia cells injected in NOD/LtSz-scid/IL-2Rgamma null mice generate a faster and more efficient disease compared to other NOD/scid-related strains. Int. J. Cancer 2008, 123, 2222-2227. [CrossRef] [PubMed]

228. Saland, E.; Boutzen, H.; Castellano, R.; Pouyet, L.; Griessinger, E.; Larrue, C.; de Toni, F.; Scotland, S.; David, M.; Danet-Desnoyers, G.; et al. A robust and rapid xenograft model to assess efficacy of chemotherapeutic agents for human acute myeloid leukemia. Blood Cancer J. 2015, 5, e297. [CrossRef]

229. Nabbouh, A.I.; Hleihel, R.S.; Saliba, J.L.; Karam, M.M.; Hamie, M.H.; Wu, H.-C.J.H.-C.J.M.; Berthier, C.P.; Tawil, N.M.; Bonnet, P.-A.A.; Deleuze-Masquefa, C.; et al. Imidazoquinoxaline derivative EAPB0503: A promising drug targeting mutant nucleophosmin 1 in acute myeloid leukemia. Cancer 2017, 123, 1662-1673. [CrossRef]

230. El-Houjeiri, L.; Saad, W.; Hayar, B.; Aouad, P.; Tawil, N.; Abdel-Samad, R.; Hleihel, R.; Hamie, M.; Mancinelli, A.; Pisano, C.; et al. Antitumor Effect of the Atypical Retinoid ST1926 in Acute Myeloid Leukemia and Nanoparticle Formulation Prolongs Lifespan and Reduces Tumor Burden of Xenograft Mice. Mol. Cancer Ther. 2017, 16, 2047-2057. [CrossRef]

231. Mu, H.; Konopleva, M.; Jacamo, R.; Carter, B.Z.; McQueen, T.; Andreeff, M. Comparison of Induction Chemotherapy in NSG and NOD- Rag1 ${ }^{\text {null }}$ IL2rg ${ }^{\text {null }}$ Mouse Models of FLT3 Mutant AML. Blood 2017, 130, 2692.

232. Cany, J.; van der Waart, A.B.; Tordoir, M.; Franssen, G.M.; Hangalapura, B.N.; de Vries, J.; Boerman, O.; Schaap, N.; van der Voort, R.; Spanholtz, J.; et al. Natural killer cells generated from cord blood hematopoietic progenitor cells efficiently target bone marrow-residing human leukemia cells in NOD/SCID/IL2Rg(null) mice. PLoS ONE 2013, 8, e64384.

233. Cany, J.; Roeven, M.W.H.; Hoogstad-van Evert, J.S.; Hobo, W.; Maas, F.; Franco Fernandez, R.; Blijlevens, N.M.A.; van der Velden, W.J.; Huls, G.; Jansen, J.H.; et al. Decitabine enhances targeting of AML cells by CD34(+) progenitor-derived NK cells in NOD/SCID/IL2Rg(null) mice. Blood 2018, 131, 202-214. [CrossRef] [PubMed]

234. Hayata, I.; Ishihara, T.; Hirashima, K.; Sado, T.; Yamagiwa, J. Partial deletion of chromosome No. 2 in myelocytic leukemias of irradiated C3H/He and RFM mice. J. Natl. Cancer Inst. 1979, 63, 843-848. [CrossRef]

235. Fredrickson, T.N.; Langdon, W.Y.; Hoffman, P.M.; Hartley, J.W.; Morse, H.C., 3rd. Histologic and cell surface antigen studies of hematopoietic tumors induced by Cas-Br-M murine leukemia virus. J. Natl. Cancer Inst. 1984, 72, 447-454. [PubMed]

236. Askew, D.S.; Bartholomew, C.; Buchberg, A.M.; Valentine, M.B.; Jenkins, N.A.; Copeland, N.G.; Ihle, J.N. His-1 and His-2: Identification and chromosomal mapping of two commonly rearranged sites of viral integration in a myeloid leukemia. Oncogene 1991, 6, 2041-2047. [PubMed]

237. Rassart, E.; Houde, J.; Denicourt, C.; Ru, M.; Barat, C.; Edouard, E.; Poliquin, L.; Bergeron, D. Molecular Analysis and Characterization of Two Myeloid Leukemia Inducing Murine Retroviruses. Curr. Top. Microbiol. Immunol. 1996, 211, 201-210. [PubMed]

238. Bergeron, D.; Poliquin, L.; Houde, J.; Barbeau, B.; Rassart, E. Analysis of proviruses integrated in Fli-1 and Evi-1 regions in Cas-Br-E MuLV-induced non-T-, non-B-cell leukemias. Virology 1992, 191, 661-669. [CrossRef]

239. Bergeron, D.; Poliquin, L.; Kozak, C.A.; Rassart, E. Identification of a common viral integration region in Cas-Br-E murine leukemia virus-induced non-T-, non-B-cell lymphomas. J. Virol. 1991, 65, 7-15.

240. Mucenski, M.L.; Taylor, B.A.; Jenkins, N.A.; Copeland, N.G. AKXD recombinant inbred strains: Models for studying the molecular genetic basis of murine lymphomas. Mol. Cell. Boil. 1986, 6, 4236-4243. [CrossRef]

241. Mucenski, M.L.; Taylor, B.A.; Ihle, J.N.; Hartley, J.W.; Morse, H.C., 3rd; Jenkins, N.A.; Copeland, N.G. Identification of a common ecotropic viral integration site, Evi-1, in the DNA of AKXD murine myeloid tumors. Mol. Cell. Biol. 1988, 8, 301-308. [CrossRef] [PubMed]

242. Fredrickson, T.N.; Silver, J.E. Susceptibility to Friend helper virus leukemias in CXB recombinant inbred mice. J. Exp. Med. 1983, 158, 1693-1702. 
243. Silver, J.; Buckler, C.E. A preferred region for integration of Friend murine leukemia virus in hematopoietic neoplasms is closely linked to the Int-2 oncogene. J. Virol. 1986, 60, 1156-1158. [PubMed]

244. Chesebro, B.; Portis, J.L.; Wehrly, K.; Nishio, J. Effect of murine host genotype on MCF virus expression, latency, and leukemia cell type of leukemias induced by Friend murine leukemia helper virus. Virology 1983, 128, 221-233. [CrossRef]

245. Bordereaux, D.; Fichelson, S.; Sola, B.; Tambourin, P.E.; Gisselbrecht, S. Frequent involvement of the fim-3 region in Friend murine leukemia virus-induced mouse myeloblastic leukemias. J. Virol. 1987, 61, 4043-4045. [PubMed]

246. Nazarov, V.; Wolff, L. Novel integration sites at the distal 3' end of the c-myb locus in retrovirus-induced promonocytic leukemias. J. Virol. 1995, 69, 3885-3888. [PubMed]

247. Shen-Ong, G.L.; Wolff, L. Moloney murine leukemia virus-induced myeloid tumors in adult BALB/c mice: Requirement of c-myb activation but lack of v-abl involvement. J. Virol. 1987, 61, 3721-3725. [PubMed]

248. Bedigian, H.G.; Johnson, D.A.; Jenkins, N.A.; Copeland, N.G.; Evans, R. Spontaneous and induced leukemias of myeloid origin in recombinant inbred BXH mice. J. Virol. 1984, 51, 586-594. [PubMed]

249. Copeland, N.G.; Buchberg, A.M.; Gilbert, D.J.; Jenkins, N.A. Recombinant Inbred Mouse Strains: Models for Studying the Molecular Genetic Basis of Myeloid Tumorigenesis. Curr. Top. Microbiol. Immunol. 1989, 149, $45-57$.

250. Nakamura, T.; Largaespada, D.A.; Shaughnessy, J.D.; Jenkins, N.A.; Copeland, N.G. Cooperative activation of Hoxa and Pbx1-related genes in murine myeloid leukaemias. Nat. Genet. 1996, 12, 149-153. [CrossRef]

251. Moskow, J.J.; Bullrich, F.; Huebner, K.; Daar, I.O.; Buchberg, A.M. Meis1, a PBX1-related homeobox gene involved in myeloid leukemia in BXH-2 mice. Mol. Cell. Boil. 1995, 15, 5434-5443. [CrossRef] [PubMed]

252. Li, J.; Shen, H.; Himmel, K.L.; Dupuy, A.J.; Largaespada, D.A.; Nakamura, T.; Shaughnessy, J.D.; Jenkins, N.A.; Copeland, N.G. Leukaemia disease genes: Large-scale cloning and pathway predictions. Nat. Genet. 1999, 23, 348-353. [CrossRef] [PubMed]

253. Buchberg, A.M.; Bedigian, H.G.; Jenkins, N.A.; Copeland, N.G. Evi-2, a common integration site involved in murine myeloid leukemogenesis. Mol. Cell. Boil. 1990, 10, 4658-4666. [CrossRef] [PubMed]

254. Largaespada, D.A.; Brannan, C.I.; Jenkins, N.A.; Copeland, N.G. Nf1 deficiency causes Ras-mediated granulocyte/macrophage colony stimulating factor hypersensitivity and chronic myeloid leukaemia. Nat. Genet. 1996, 12, 137-143. [CrossRef] [PubMed]

255. Tian, E.; Sawyer, J.R.; Largaespada, D.A.; Jenkins, N.A.; Copeland, N.G.; Shaughnessy, J.D. Evi27 encodes a novel membrane protein with homology to the IL17 receptor. Oncogene 2000, 19, 2098-2109. [CrossRef]

256. Peterson, L.F.; Zhang, D.-E. The 8;21 translocation in leukemogenesis. Oncogene 2004, 23, 4255-4262. [CrossRef] [PubMed]

257. Kozu, T.; Miyoshi, H.; Shimizu, K.; Maseki, N.; Kaneko, Y.; Asou, H.; Kamada, N.; Ohki, M. Junctions of the AML1/MTG8(ETO) fusion are constant in $\mathrm{t}(8 ; 21)$ acute myeloid leukemia detected by reverse transcription polymerase chain reaction. Blood 1993, 82, 1270-1276.

258. Tonks, A.; Pearn, L.; Musson, M.; Gilkes, A.; Mills, K.I.; Burnett, A.K.; Darley, R.L. Transcriptional dysregulation mediated by RUNX1-RUNX1T1 in normal human progenitor cells and in acute myeloid leukaemia. Leukemia 2007, 21, 2495-2505. [CrossRef]

259. De Guzman, C.G.; Warren, A.J.; Zhang, Z.; Gartland, L.; Erickson, P.; Drabkin, H.; Hiebert, S.W.; Klug, C.A. Hematopoietic Stem Cell Expansion and Distinct Myeloid Developmental Abnormalities in a Murine Model of the AML1-ETO Translocation. Mol. Cell. Boil. 2002, 22, 5506-5517. [CrossRef]

260. Crozatier, M.; Meister, M. Drosophila haematopoiesis. Cell. Microbiol. 2007, 9, 1117-1126. [CrossRef]

261. Wildonger, J. The $\mathrm{t}(8 ; 21)$ translocation converts AML1 into a constitutive transcriptional repressor. Development 2005, 132, 2263-2272. [CrossRef] [PubMed]

262. Lebestky, T. Specification of Drosophila Hematopoietic Lineage by Conserved Transcription Factors. Science 2000, 288, 146-149. [CrossRef] [PubMed] 
263. Osman, D.; Gobert, V.; Ponthan, F.; Heidenreich, O.; Haenlin, M.; Waltzer, L. A Drosophila model identifies calpains as modulators of the human leukemogenic fusion protein AML1-ETO. Proc. Natl. Acad. Sci. USA 2009, 106, 12043-12048. [CrossRef] [PubMed]

264. Breig, O.; Bras, S.; Martinez Soria, N.; Osman, D.; Heidenreich, O.; Haenlin, M.; Waltzer, L. Pontin is a critical regulator for AML1-ETO-induced leukemia. Leukemia 2014, 28, 1271-1279. [CrossRef] [PubMed]

(C) 2019 by the authors. Licensee MDPI, Basel, Switzerland. This article is an open access article distributed under the terms and conditions of the Creative Commons Attribution (CC BY) license (http://creativecommons.org/licenses/by/4.0/). 